
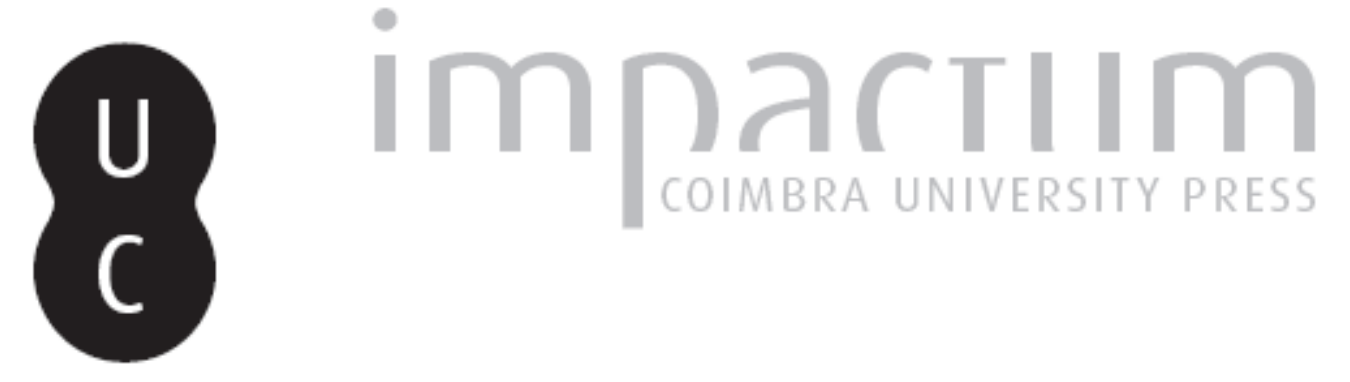

\title{
O conceito de acidente de trabalho: conexão com a relação laboral
}

\section{Autor(es): $\quad$ Cardoso, Maria Beatriz}

Publicado por: Imprensa da Universidade de Coimbra

URL persistente:

URI:http://hdl.handle.net/10316.2/42159

DOI:

DOI:http://dx.doi.org/10.14195/1647-8630_26_3

Accessed : $\quad$ 26-Apr-2023 10:24:21

A navegação consulta e descarregamento dos títulos inseridos nas Bibliotecas Digitais UC Digitalis, UC Pombalina e UC Impactum, pressupõem a aceitação plena e sem reservas dos Termos e Condições de Uso destas Bibliotecas Digitais, disponíveis em https://digitalis.uc.pt/pt-pt/termos.

Conforme exposto nos referidos Termos e Condições de Uso, o descarregamento de títulos de acesso restrito requer uma licença válida de autorização devendo o utilizador aceder ao(s) documento(s) a partir de um endereço de IP da instituição detentora da supramencionada licença.

Ao utilizador é apenas permitido o descarregamento para uso pessoal, pelo que o emprego do(s) título(s) descarregado(s) para outro fim, designadamente comercial, carece de autorização do respetivo autor ou editor da obra.

Na medida em que todas as obras da UC Digitalis se encontram protegidas pelo Código do Direito de Autor e Direitos Conexos e demais legislação aplicável, toda a cópia, parcial ou total, deste documento, nos casos em que é legalmente admitida, deverá conter ou fazer-se acompanhar por este aviso.

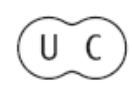




\title{
0 conceito de acidente de trabalho Conexão com a relação laboral
}

\author{
Maria Beatriz Cardoso ${ }^{1}$
}

Resumo: 0 conceito de acidente de trabalho. Conexão com a relação laboral.

Este texto analisa o conceito de acidente de trabalho, na perspetiva de o mesmo pressupor, como seu requisito essencial e etiológico, uma relação de causalidade com o trabalho amplamente considerado, abrangendo, portanto, quer os riscos inerentes à execução de trabalho, quer aqueles que resultam da relação laboral.

Palavras-chave: Acidente de trabalho; conceito; requisitos.

Summary: The work accident concept. Connection with the employment relationship. This paper analyzes the work accident concept, assuming as its essential and etiological requirement, a causal relationship with work in general terms, including therefore the risks inherent to its execution, and also those resulting from the employment relationship.

Key-words: Work accident; concept; requirements.

\section{A responsabilidade por acidente de trabalho}

Os acidentes de trabalho começaram por ser submetidos ao regime geral da responsabilidade civil extracontratual ou aquiliana, cujo pressuposto fundamental é a existência de culpa por parte do lesante, impendendo o ónus da prova da mesma sobre o lesado, o que deixava muitos acidentes sem reparação: não havia culpa de ninguém ou, havendo-a, o sinistrado não conseguia fazer a sua prova ${ }^{2}$.

\footnotetext{
Advogada. Pós-graduada em Direito do Trabalho

2 Era mais difícil a prova da culpa tratando-se de um acidente causado por uma máquina, quer pela complexidade da prova das deficiências da mesma, o que requeria conhecimentos técnicos, quer por virtude da dificuldade em imputar ao empregador a culpa do mau funcionamento de uma máquina que ele adquirira a um terceiro - Cfr. MARTINEZ, PEDRO ROMANO Direito do Trabalho,6. a edição, Almedina, 2013, p. 778.
} 
Imperava a ideia de que as duas partes do contrato de trabalho tinham uma posição igual, pelo que não podia ser responsabilizada uma delas pelos infortúnios que adviessem à outra.

Considerava-se que não existia um risco específico do trabalho; os acidentes ocorridos no âmbito laboral integravam-se nos riscos normais que qualquer atividade humana comporta ${ }^{3}$. $\mathrm{O}$ acidente era tido como um azar do lesado, nas palavras de PEDRO ROMANO MARTINEZ4, o que redundava numa flagrante injustiça, pois os riscos que empregador e trabalhador corriam não eram equiparáveis: aquele, por norma, arriscava apenas o seu património, enquanto este último arriscava a sua integridade física e a própria vida.

Muito pelo labor judicial, foi nascendo a ideia de que, sendo uma das partes desse contrato claramente mais fraca e sendo também ela a que corria maiores riscos, carecia de uma especial proteção. A segurança do trabalhador não podia ficar exclusivamente a cargo dele próprio, pelo que o empregador devia ser onerado com a mesma, quer por via de prevenção, quer por via de reparação.

ANTUNES VARELA, a propósito do valor pedagógico-educativo da responsabilidade baseada na culpa, reconhecia que «Hálargos e importantes setores da vida em que as necessidades sociais de segurança se têm mesmo de sobrepor às considerações de justiça alicerçadas sobre o plano das situações individuais. Torna-se necessário, quando assim seja, temperar o pensamento clássico da culpa com certos ingredientes sociais de caráter objetivo. Foi no dominio dos acidentes de trabalho que primeiro se chegou a tal conclusão ${ }^{5}$ ».

Desta forma, começou a delinear-se um ramo autónomo e especial do direito privado, o Direito do Trabalho, com o escopo de conferir uma proteção acrescida ao trabalhador sinistrado, como parte reconhecidamente mais débil ${ }^{6}$.

À responsabilidade civil extracontratual subjetiva - e depois de alguma tendência para recorrer ao regime da responsabilidade contratual ${ }^{7}$, o qual

3 Como descreve GOMES, JÚLIO MANUEL VIEIRA, in 0 Acidente de Trabalho - 0 acidente in itinere e a sua descaraterização, Coimbra Editora, 2013, p. 10.

4 0b. cit., p. 777.

5 In Das Obrigações em geral, 4. ${ }^{\text {a }}$ edição, Almedina, 1982, p. 557.

6 Vide FERNANDES, MONTEIRO, in Noções Fundamentais de Direito do Trabalho, 5. a edição, Almedina, 1986: «Foram as formas extremas e particularmente gritantes de exploração, próprias da organização da produção em termos fabris, que forçaram os poderes públicos, por todo o lado em que o surto da industrialização ocorria, a abandonar a "neutralidade" exigida pelos princípios do liberalismo económico e intervir numa necessária definição das condições em que o trabalho era prestado nas fábricas».

7 Uma obrigação contratual de segurança a cargo do empregador, como refere GOMES, JÚLIO MANUEL VIEIRA ob. cit. p. 11. 
também não se mostrava capaz de conferir a proteção de que o trabalhador precisava, porquanto deixava de fora as situações em que não houvesse uma violação contratual por parte do empregador - sucedeu a responsabilidade objetiva ou pelo risco: na Alemanha, com a Lei de 6 de Julho de 1884, em Inglaterra, com a Lei de 6 de Agosto 1897 e em França, com a Lei de 9 de Abril de 1898.

Em Portugal, a responsabilidade objetiva do empregador surgiu durante a $1^{\text {a }}$ República, com a Lei n. ${ }^{\circ}$ 83, de 24 de Julho de 1913.

A figura da responsabilidade civil objetiva nasceu, assim, para resolver a necessidade de reparação dos acidentes de trabalho e assumindo, naturalmente, um caráter excecional, porque independente da existência de culpa ${ }^{8}$.

Posteriormente, esta figura passou a ser utilizada noutros domínios em que igualmente se impunha garantir de modo especial os lesados, como foi o caso dos acidentes de viação, com a vulgarização do uso do automóvel e a proliferação da sinistralidade rodoviária.

Esta vertente da responsabilidade dispensa a existência de culpa, bastando a verificação de um dano para que haja obrigação de o reparar e assenta no princípio de que quem tira benefício de uma atividade e dos próprios riscos que a mesma gera, deve suportar também as consequências prejudiciais que dela possam resultar - ubi commoda, ibi incommoda.

$\mathrm{O}$ risco subjacente à responsabilidade pelos acidentes de trabalho começou por ser configurado como um risco profissional, que postula a existência de uma relação de causa e efeito, ou nexo de causalidade, entre o acidente (evento lesivo) e o trabalho executado: só constituía acidente de trabalho aquele que decorresse dos riscos próprios da atividade profissional desenvolvida.

Uma outra conceção, porém, foi ganhando relevo, com o intuito de também acolher no âmbito da tutela infortunística outros eventos danosos, ocorridos ou não no local e tempo de trabalho e não resultantes diretamente do desempenho da prestação de trabalho, mas indubitavelmente merecedores daquela tutela.

Evoluiu-se, então, para a teoria do risco económico ou risco de autoridade, ou, ainda, risco de integração empresarial ${ }^{9}$, nos termos da qual se prescinde do nexo de causalidade entre a prestação do trabalho e o acidente,

8 «A imposição desta responsabilidade constituirá, por outro lado, um estímulo eficaz ao aperfeiçoamento da empresa, tendente a diminuir o número e a gravidade dos riscos na prestação do trabalho, bem como a segurar os empregados contra os acidentes a que continuamente se encontram expostos» salienta VARELA, ANTUNES ob. cit. p. 559.

90 risco de ter trabalhadores ao serviço, como refere RAMALH0, MARIA DO ROSÁRIO PALMA, in Direito do Trabalho, Parte II - Situações Laborais Individuais, Almedina, 2010, p. 827. 
porquanto o que é determinante é o risco genérico ligado à autoridade do empregador.

A reparação de um acidente está, por conseguinte, dependente de a respetiva causa constituir um risco da situação laboral amplamente considerada, não se restringindo aos riscos gerados pelo desempenho do trabalho propriamente dito, e abarcando, outrossim, todos aqueles a que o trabalhador se expõe pelo facto de colocar no mercado a sua força ou capacidade de trabalho ${ }^{10}$, num manifesto fenómeno de socialização do risco ${ }^{11}$.

O regime legal português, atualmente consagrado na Lei n. ${ }^{\circ}$ 98/200912, de 4 de Setembro, segue claramente a teoria do risco económico, permitindo conferir tutela legal quer aos acidentes laborais comuns, ocorridos no local e tempo de trabalho, quer a outros que, embora se relacionem de forma mais difusa com a prestação do trabalho, justificam ainda proteção, como sucede, por exemplo, no caso dos acidentes in itinere ${ }^{13}$, dos acidentes ocorridos fora do local de trabalho, mas na execução de serviços espontaneamente prestados e de que possa resultar proveito económico para o empregador ou, ainda, dos acidentes no exercício do direito de reunião, no local de trabalho ou fora dele.

A sucessão de regimes legais tem sido pautada por um progressivo aumento dos direitos dos sinistrados e das responsabilidades dos empregadores e respetivas seguradoras, o que é particularmente visível no alargamento do conceito de acidente de trabalho e do elenco das prestações em dinheiro e em espécie.

PEDRO ROMANO MARTINEZ entende que o regime jurídico dos acidentes de trabalho assenta nos pressupostos básicos da responsabilidade civil extracontratual, embora apresente algumas especificidades. Trata-se, segundo este Autor, de um regime de responsabilidade civil objetiva, caso contrário não se entenderiam as disposições relativas à exclusão da

10 Cfr. LEITÃO, LUÍS MENEZES, in Direito do Trabalho, Almedina, 2010, p. 440.

11 CARVALHO, JOSÉ AUGUSTO CRUZ DE,in Acidentes de Trabalho e Doenças Profissionais, Legislação Anotada, Petrony, 2. ${ }^{\text {a }}$ edição, 1983, p. 10, refere que «...não se trata já de um risco específico de natureza profissional, traduzido numa ligação direta acidente-trabalho, mas sim de um risco genérico, ligado à noção ampla de autoridade patronal».

12 Em Portugal, os acidentes de trabalho começaram por ser regulados pela Lei n. ${ }^{\circ} 83$, de 24 de Julho de 1913, a qual apenas contemplava o risco profissional. Seguiu-se o Decreto n. ${ }^{\circ} 5637$, de 10 de Maio de 1919, que instituiu o seguro obrigatório nesta matéria. Aquela primeira lei foi substituída, no Estado Novo, pela Lei n. ${ }^{0} 1942$, de 27 de Julho de 1936, a qual consagrou o risco económico ou de autoridade. Sucedeu-lhe a Lei n. ${ }^{\circ}$ 2127, de 3 de Agosto de 1965, a que se seguiria a Lei n. ${ }^{0}$ 100/97, de 13 de Setembro, que foi, entretanto, revogada pela Lei n. ${ }^{0}$ 98/2009, de 4 de Setembro.

${ }_{13}$ Figura de origem pretoriana, que se destina a dar proteção aos acidentes ocorridos no trajeto laboral. 
responsabilidade: "(...) do disposto no art. ${ }^{\circ} 14^{a}$ da LAT, ao estabelecer que há o dever de indemnizar salvo nos casos aí previstos, conclui-se que foi estabelecida uma responsabilidade sem culpa ${ }^{14}$ ».

Já na perspetiva de LUIS MENEZES LEITÃO não se verificam os pressupostos da responsabilidade civil, por ausência do nexo de imputação.

Para este Autor, o regime jurídico dos acidentes de trabalho está mais próximo do sistema de segurança social do que da responsabilidade civil, pois apesar de o legislador ter pretendido criar um sistema de responsabilidade civil baseado no risco, constituiu um dever de assistência social ${ }^{15}$ e defende mesmo a natureza mais alimentar do que indemnizatória dessa reparação ${ }^{16}$.

CARLOS ALEGRE avança com a justificação de que o princípio que enforma a reparação por acidente de trabalho é o de o sinistrado nada ter de despender com o seu tratamento e recuperação para a vida ativa, sendo, por outro lado, indemnizado em função do respetivo salário. Não se pretende reparar integralmente o dano, pelo que as prestações em dinheiro assumem um caráter meramente compensatório ${ }^{17}$.

Na nossa opinião, é de responsabilidade civil que se trata e que deve tratar-se: uma responsabilidade objetiva, assente no risco económico ou empresarial, ou, ainda, de autoridade do empregador.

O fenómeno da assistência social está confiado ao poder público, tal como, de resto, está a contingência das doenças profissionais.

No entanto, não deixamos de reconhecer algum fundamento ao citado ponto de vista, pois, como veremos de seguida, o regime legal dos acidentes de trabalho apresenta vários traços mais próximos de verdadeira segurança social do que de responsabilidade civil, tornando, de resto, a exploração privada do correspondente seguro financeiramente muito problemática.

14 Ob. cit. p. 770.

15 In Acidentes de Trabalho e Responsabilidade Civil (A Natureza Jurídica da Reparação de Danos Emergentes de Acidentes de Trabalho e a Distinção entre as Responsabilidades Obrigacional e Delitual, R0A, 1993, p. 825 e ss.

16 In A reparação de danos emergentes de acidentes de trabalho, Estudos do Instituto de Direito do Trabalho, Vol. I, 2001, p. 568: "A nosso ver, o facto de o regime jurídico dos acidentes de trabalho atribuir uma reparação limitada demonstra que ele apenas limitadamente exerce uma função indemnizatória. A sua função principal não é a de reparar o dano sofrido mas sim a de tutelar a situação do trabalhador que, economicamente dependente de uma prestação de trabalho, vê essa prestação impossibilitada pela sua incapacidade física, ficando, em consequência, sem meios de subsistência. Nesse pressuposto podemos afirmar que a reparação de danos emergentes de acidentes de trabalho não tem um caráter estritamente reparatório, sendo a sua função antes de caráter alimentar.»

17 Ob. cit., p. 77. 
O n. 3 do art. ${ }^{\circ} 63^{\circ}$ da Constituição da República Portuguesa prescreve a integração dos acidentes de trabalho no sistema da segurança social, mas essa integração, sucessivamente proclamada e protelada ao longo de vários anos, acabou por ser abandonada.

A atual LAT prevê mesmo a obrigatoriedade de transferência da responsabilidade nela prevista para uma empresa de seguros, tipificando a violação dessa obrigação como uma contraordenação muito grave, cfr. n. ${ }^{\circ} 1$ do art. ${ }^{\circ} 171^{\circ}$.

Com efeito, face à crise das finanças públicas, a opção do legislador tem sido a manutenção do sistema reparatório dos acidentes de trabalho no setor segurador ${ }^{18,19}$, e não a sua transferência para o Estado, como encargo da segurança social.

Adicionalmente, o legislador vai pincelando o regime legal dos acidentes de trabalho com tonalidades típicas de assistência social, desligando-o progressivamente do âmbito da responsabilidade civil, ao mesmo tempo que -paradoxalmente ou nem tanto - é cada vez mais cauteloso e restritivo na delineação do regime da segurança social, em especial na atribuição de benefícios.

Damos nota também do entendimento nesta matéria de FLORBELA DE ALMEIDA PIRES ${ }^{20}$ : "No tocante ao sistema português, verificámos que existe um desfasamento entre os imperativos constitucionais, que apontam para a construção de um sistema de direito público, e o sistema vigente que se mantém nos moldes da responsabilidade civil com seguro obrigatório, não havendo perspectivas de mudança quer no plano constitucional quer no plano infra constitucional».

A Autora invoca mesmo uma inconstitucionalidade por omissão ${ }^{21}$, atento o que designa por incumprimento da obrigação legiferante concreta que emerge do n. ${ }^{\circ} 3$ do rt. $^{\circ} 63^{\circ}$ da CRP, bem como uma inconstitucionalidade por ação, patente na Lei 100/97, ao manter a proteção dos acidentes de trabalho fora do sistema de segurança social.

Parece-nos inquestionável que a manutenção da reparação dos acidentes de trabalho num sistema de seguro privado representa uma vantagem para

18 Segundo MARTINEZ, PEDRO ROMANO, a opção pelo seguro privado obrigatório visou «garantir a reparação do lesado sem pôr em causa o substrato económico da empresa.», ob. cit., p. 815.

19 XAVIER, BERNARDO LOB0, ob. cit., p. 960, manifesta igual pensamento, referindo que a solução legal tem em vista a «proteç̧ão do trabalhador (que tem aí uma garantia da efetivação dos seus direitos), como para a própria proteç̧ão das empresas (cujo património, designadamente em caso de empresas de pequena dimensão, poderia ficar substancialmente afectado.»

20 In Seguro de Acidentes de Trabalho, Lex, 1999, p. 83.

21 Ob. cit., p. 30. 
os sinistrados. Contudo, é frequente ver ressaltado o caráter incompleto da reparação prevista no regime legal dos acidentes de trabalho, principalmente por não abranger os danos não patrimoniais.

Trata-se de uma decorrência de se estar perante uma responsabilidade objetiva que visa ressarcir o dano laboral, ou seja, a redução da capacidade de trabalho e a morte. Ademais, as prestações são exclusivamente as que a lei prevê, em normas que são taxativas, e o respetivo valor encontra-se sujeito a critérios legais imperativos, tudo num claro reverso do caráter objetivo da responsabilidade que lhes está subjacente ${ }^{22}$.

Não obstante, essa aparente limitação parece-nos largamente compensada por outros aspetos do mesmo regime, dos quais, entre vários outros, destacamos:

- a irrelevância da culpa do lesado, exceto se a mesma for causa exclusiva do acidente,

- a indisponibilidade dos direitos,

- a diversidade e o alcance de prestações em espécie,

- a reparação da parcela da incapacidade relativa a doença ou lesão preexistente como se a mesma fosse resultante do acidente,

- a atribuição de uma incapacidade permanente mercê do mero decurso do tempo, através da conversão da incapacidade temporária,

- a bonificação do grau de incapacidade permanente em $50 \%$ por virtude da idade e

- a longevidade da obrigação de reparação, mediante a atribuição de pensões vitalícias, atualizáveis anualmente e, bem assim, suscetíveis de aumentos extraordinários, determinados pela revisão da incapacidade, agora sem limite de prazo, e pelo atingimento da idade da reforma, no caso de alguns beneficiários por morte.

Torna-se, pois, evidente que, em múltiplos aspetos, a reparação do acidente de trabalho transcende a indemnização dos danos concretos em presença, no tal fenómeno cruzado de aproximação do regime dos acidentes de trabalho a uma proteção típica de segurança social e de afastamento desta do que lhe é mais caraterístico, através da redução ou mesmo supressão de benefícios.

22 MARTINEZ, PEDRO ROMANO aponta uma dupla limitação, por um lado, através da delimitação do conceito de acidente de trabalho e, por outro, na tipificação dos danos ressarcíveis -ob. cit. p. 784 . 
E apesar de o seguro de acidentes de trabalho revestir a natureza de um seguro de responsabilidade civil ${ }^{23}$, como emerge do n. ${ }^{\circ} 3$ do artigo $138^{\circ}$ do DL 72/2008, de 16 de Abril, que aprova o regime jurídico do contrato de seguro, o facto é que em muitos aspetos da reparação dos acidentes de trabalho está substancialmente posto em causa o princípio do indemnizatório, consagrado, desde logo, no art. ${ }^{\circ} 128^{\circ}$ do mesmo diploma: «A prestação devida pelo segurador está limitada ao dano decorrente do sinistro até ao montante do capital seguro.»

\section{0 conceito de acidente de trabalho}

Discute-se a pertinência de a lei definir o conceito de acidente de trabalho, pois há opiniões no sentido de que o mesmo não deve ser espartilhado na respetiva letra, dando-se primazia à apreciação do intérprete, máxime do julgador, perante as circunstâncias de cada caso concreto.

Sendo a segurança e a certeza valores fundamentais de um ordenamento jurídico, não nos parece a melhor opção deixar num total vazio os contornos essenciais de uma realidade social e economicamente tão relevante como a dos acidentes de trabalho, submetidos, mais a mais, a um regime de responsabilidade objetiva.

As alterações da vida e da realidade acabam por ser acolhidas pela lei, mediante um processo adequado, que é o processo legislativo. Não se mostra curial que seja o poder judicial a definir, casuisticamente, o conceito de acidente de trabalho, por muito que o julgador deva exercer a sua influência na conformação da lei à vida prática, procurando um compromisso entre o texto legal e a necessidade de acolher as situações que entende merecerem tutela legal.

Ademais, a não consagração legal do conceito de acidente de trabalho implicaria necessariamente um aumento da litigância, habitualmente já muito elevada, exacerbando a tendência de cada um para analisar a situação, na perspetiva da sua qualificação ou não como acidente de trabalho, do modo mais conforme aos respetivos interesses.

No nosso ordenamento jurídico, a opção vigente é a da definição por via legal do conceito. Assim, a Lei 98/2009, no art. ${ }^{\circ} 8 .^{\circ}$, dispõe que acidente de trabalho é «aquele que se verifique no local e no tempo de trabalho e produza direta ou indiretamente lesão corporal, perturbação funcional ou

23 «No seguro de responsabilidade civil, o segurador cobre o risco de constituição, no património do segurado, de uma obrigação de indemnizar terceiros.», nos termos do art. ${ }^{\circ} 137^{\circ}$ do DL 72/2008. 
doença de que resulte redução na capacidade de trabalho ou de ganho ou a morte».

Especifica igualmente o conceito de local de trabalho como «todo o lugar em que o trabalhador se encontra ou deva dirigir-se em virtude do seu trabalho e em que esteja, direta ou indiretamente, sujeito ao controlo do empregador» e, bem assim, o conceito de tempo de trabalho: «além do período normal de trabalho, o que precede o seu início, em atos de preparação ou com ele relacionados, e o que se lhe segue, em atos também com ele relacionados, e ainda as interrupções normais ou forçosas de trabalho».

Tipifica, ainda, as situações de extensão do conceito ao longo do art. ${ }^{\circ}$ 9. .

Vejamos uma pequena síntese comparativa do conceito de acidente de trabalho em alguns países, elaborada com base nas Tabelas MISSOC ${ }^{24}$ e bem reveladora das diferentes perspetivas existentes nesta matéria:

\begin{tabular}{|c|c|c|c|c|c|c|c|}
\hline Portugal & Espanha & Itália & França & Áustria & Bélgica & Alemanha & Finlândia \\
\hline \begin{tabular}{|l} 
Acidente \\
ocorrido no local \\
e no tempo de \\
trabalho, e que \\
produza direta \\
ou indiretamente \\
uma lesão física, \\
perturbação \\
funcional ou \\
doença de que \\
resulte morte ou \\
incapacidade \\
para o trabalho
\end{tabular} & \begin{tabular}{|l} 
Lesão \\
corporal \\
sofrida por \\
ocasião ou \\
por \\
consequên- \\
cia do \\
trabalho
\end{tabular} & \begin{tabular}{|l} 
Lesão \\
ocorrida no \\
trabalho por \\
uma causa \\
violenta em \\
conexão com \\
um risco \\
relacionado \\
com a \\
atividade \\
desenvolvida, \\
que resulta \\
em morte ou \\
incapacidade
\end{tabular} & \begin{tabular}{|l|} 
Acidente \\
que, \\
qualquer \\
que seja a \\
causa, \\
ocorre por \\
efeito ou \\
por \\
ocasião \\
do \\
trabalho \\
\end{tabular} & \begin{tabular}{|l|} 
Acidente \\
ocorrido \\
no \\
trabalho, \\
durante o \\
tempo de \\
trabalho \\
ou como \\
resultado \\
da \\
atividade \\
realizada
\end{tabular} & \begin{tabular}{|l} 
Lesão \\
ocorrida \\
durante e \\
como \\
resultado \\
da \\
execução \\
do contrato \\
de trabalho \\
e que \\
provoca \\
uma lesão
\end{tabular} & \begin{tabular}{|l|} 
Lesão \\
causada \\
por \\
acidente \\
ocorrido na \\
empresa \\
e/ou em \\
conexão \\
com uma \\
atividade \\
profissional
\end{tabular} & \begin{tabular}{|l} 
Lesão \\
ocorrida \\
no trabalho \\
ou em \\
circunstân- \\
cias \\
decorren- \\
tes de um \\
emprego
\end{tabular} \\
\hline
\end{tabular}

A doutrina e a jurisprudência portuguesas, na densificação do conceito legal de acidente de trabalho, vêm apontando o mesmo como o acontecimento súbito, de verificação inesperada e origem externa, que provoca direta ou indiretamente lesão corporal, perturbação funcional ou doença de que resulte a morte ou redução da capacidade de trabalho ou de ganho do trabalhador,

24 Mutual Information System on Social Protection, disponiveis em http://www.missoc.org/MISSOC/INFORMATIONBASE/COMPARATIVETABLES/MISSOCDATABASE/comparativeTableSearch_PREVIOUS.jsp Trata-se de uma iniciativa da Comissão Europeia que visa fornecer informação detalhada, comparável e regularmente atualizada acerca dos sistemas de proteção social em trinta e dois países da União Europeia, bem como na Islândia, Liechtenstein, Noruega e Suiça, concretamente nas áreas relativas ao financiamento, saúde, doença, maternidade, invalidez, velhice, sobrevivência, acidentes de trabalho e doenças profissionais, família, desemprego, recursos mínimos garantidos e cuidados de longa duração. 
encontrando-se este no local e no tempo de trabalho, ou nas situações em que é consagrada a extensão do conceito de acidente de trabalho ${ }^{25}$.

MARIA DO ROSÁRIO PALMA RAMALHO define acidente de trabalho como «o evento súbito e imprevisto, ocorrido no local e no tempo de trabalho, que produz uma lesão corporal ou psíquica ao trabalhador que afecte a sua capacidade de ganho ${ }^{26} »$.

PEDRO ROMANO MARTINEZ considera que «O acidente de trabalho pressupõe que seja súbito o seu aparecimento, assenta numa ideia de imprevisibilidade quanto à sua verificação e deriva de fatores exteriores ${ }^{27}$ ».

Há, todavia, entendimentos segundo os quais a origem externa não é uma caraterística essencial do acidente de trabalho, porquanto a mesma não se verifica nas hérnias, entorses, distensões musculares, etc, por não resultarem de uma causa exterior, mas do esforço desenvolvido pelo trabalhador ${ }^{28}$.

Não nos parece a melhor abordagem, pois tratando-se de lesões internas causadas por um esforço físico na execução do trabalho - únicas que podem importar neste âmbito - a origem é claramente externa: consiste no referido esforço.

Obviamente, tem de ocorrer um evento em sentido naturalístico ${ }^{29}$ para que se possa falar de acidente de trabalho; é o caso do trabalhador que contrai uma lesão muscular ao pegar num objeto pesado, ao fazer um gesto brusco para alcançar algo que caía ou para escapar de ser atingido por um objeto que se precipitava sobre ele. São situações que determinam um esforço anormal que, por sua vez, pode causar uma lesão ou agravar uma preexistente.

Um acidente de trabalho pressupõe sempre um facto ou evento em sentido naturalístico que tem como consequência a afetação do organismo do trabalhador, causando-lhe uma lesão, perturbação funcional ou doença.

Mas vamos encontrando descrições de alegados acidentes de trabalho com o seguinte teor: "ao levantar-me da cadeira, senti uma dor nas costas", "ao baixar-me para apanhar uma folha de papel, senti uma dor lombar", "virei-me para apanhar um parafuso e fiquei sem poder mexer o ombro com dores", "a trabalhadora, ao apertar os botões da bata, sentiu uma dor no ombro", "ao subir as escadas, fiquei com uma dor no joelho", "ao espirrar senti uma dor

\footnotetext{
25 Vide, por todos, os Acórdãos do STJ de 28/03/2007, Proc. ${ }^{\circ}$ 06S3957, e de 13/01/2010, Proc. $^{\circ}$ 1466/03.2TTPRT.S1, disponíveis em www.dgsi.pt, tal como os demais arestos referidos ao longo do presente texto, exceto se indicada fonte diversa.

26 Ob. cit., p. 823.

27 Ob. cit., p. 773.

28 Assim, GOMES, JÚLI0, ob. cit. p. 24.

${ }^{29}$ Ou seja, no plano factual, por oposição ao plano jurídico.
} 
no pescoço", que deixam antever meras manifestações de patologias naturais no local e tempo de trabalho.

Uma dor não constitui um acidente de trabalho; é consequência e manifestação ou sintoma de algo que tem de se provar em que consiste e em face do que se poderá concluir, ou não, pela verificação de um acidente de trabalho ${ }^{30}$.

Cabe aqui salientar que tal prova não é dispensada pela presunção constante do n. ${ }^{\circ} 1$ do art. $^{\circ} 10^{\circ}$ da LAT, pois esta não abrange a prova do acidente - que tem sempre de ser provado ${ }^{3132}$ - mas apenas do nexo de causalidade entre o mesmo acidente e a lesão constatada no local e no tempo de trabalho. Todavia, verifica-se com alguma frequência o recurso à mesma presunção em situações em que o que aconteceu no contexto laboral foi uma dor, um desmaio...

Para culminar, neste género de situações, e porque, quase invariavelmente, os meios complementares de diagnóstico anunciam uma doença, é por vezes associada a figura da predisposição patológica, o que constitui o passo lógico subsequente para completar o processo de importação para a reparação acidentária de realidades de outro foro.

A predisposição patológica pode definir-se como uma condição do organismo, patente ou oculta, que, mais tarde ou mais cedo, levará à eclosão de determinada doença.

No âmbito do regime legal dos acidentes de trabalho, para que a mesma figura opere, é necessária a verificação de três requisitos cumulativos:

- existência de uma lesão ou doença anterior

- ocorrência de um acidente de trabalho

- verificação de um agravamento:

- da patologia anterior, por efeito do acidente ou

- da lesão resultante do acidente, por efeito da patologia anterior.

30 Ac. TR Porto de 05/10/2015, Proc. ${ }^{\circ 666 / 11.6 T U M A I . P 2 ~ « A ~ m a n i f e s t a c ̧ a ̃ o ~ d a ~ l e s a ̃ o ~ s i g n i f i c a ~ a l g o ~ m a i s ~ d o ~ q u e ~}$ a mera verbalização de queixa do sinistrado, devendo ser constatada ou evidenciada ou, ao menos, exigindo-se que essa manifestação o seja de forma minimamente mais objetivada do que a mera verbalização da queixa.»

31 A presunção apenas dispensa a prova do nexo de causalidade entre o acidente e as lesões, não dispensando a prova da verificação do próprio acidente causador das lesões, âmbito em que se aplica o princípio geral do ónus de prova, cfr. Ac. do STJ de 19/11/2008, Proc. ${ }^{\circ} 08$ S2466.

32 No mesmo sentido, MARTINEZ, PEDRO ROMANO, para quem «Não se trata de uma presunção da existência do acidente, mas antes uma presunção de que existe nexo causal entre o acidente e a lesão ocorrida», in ob. cit. p. 861 , nota 2 . 
Ora, nas situações acima mencionadas, em que não detetamos um esforço físico capaz de gerar ou agravar lesões, mas apenas gestos e movimentos normais, apenas se verifica, em regra, o primeiro dos requisitos, sendo os restantes dois mera ficção.

Se um acidente de trabalho precipitar ou agravar uma doença latente, é justo que a reparação do mesmo considere essa realidade. Mas se a doença ou lesão anterior for a causa única do dano, então tudo ficou a dever-se à mesma e não ao evento descrito (normalmente, centrado numa sintomatologia), faltando totalmente o nexo de causalidade.

Por vezes, um gesto inofensivo e incapaz de, por si só, gerar qualquer lesão, mais não faz do que tornar mais percetível e/ou intensificar temporariamente uma sintomatologia dolorosa, não determinando qualquer agravamento da patologia de base.

Contudo, da combinação da aplicação indevida da presunção com a figura da predisposição patológica, resulta esta nova tipologia de "acidentes de trabalho", verdadeiro anátema, consumidor de recursos que deviam ser canalizados para as situações em que o trabalhador sofre um autêntico acidente de trabalho, especialmente quando o mesmo assume consequências devastadoras.

Ainda quanto à causa externa, também se encontram amiúde decisões judiciais em que se afasta o mesmo requisito com o argumento de que a lesão pode ser física ou psíquica, aparente ou oculta, interna ou externa e de manifestação imediata ou posterior.

Todavia, e salvo o devido respeito, os defensores da abolição deste requisito confundem causa com consequência. A lesão pode ser tudo aquilo, mas a sua causa nunca pode ser interna. E tanto uma como outra (causa e consequência) podem ser de natureza psíquica, na condição, obviamente, de resultar uma incapacidade para o trabalho.

A lesão proveniente do acidente não tem de ser uma lesão física ou corporal em sentido estrito; pode ser uma afeção nervosa, mental ou psíquica. Mas a sua causa tem sempre de ter uma origem no exterior do organismo do trabalhador; se a origem for interna, então não estamos perante um acidente de trabalho, mas perante o acometimento ou manifestação de uma doença natural, o que, de resto, tem elevada probabilidade de acontecer, por todo o tempo passado no local de trabalho.

Pensemos nas seguintes situações da vida real:

desabamento de uma mina que isola os trabalhadores do exterior, a grande profundidade, durante um determinado período de tempo e não 
provocando ferimentos em nenhum deles, mas causando perturbação psíquica em alguns (pânico, claustrofobia, etc);

- trabalhador que assiste a um acidente grave e trágico de um colega e que entra em depressão;

- assalto com armas de fogo a uma agência bancária em que apenas há ameaças e que deixa a funcionária do caixa em estado de choque.

Em todos os casos, estamos perante lesões não físicas ou não corporais, mas indubitavelmente, de origem externa. Divergimos aqui do entendimento de MARIA ADELAIDE DOMINGOS, VIRIATO REIS e DIOGO RAVARA, para quem «(...) não são indemnizáveis as lesões de outra natureza que não sejam corporais ou funcionais. Assim, se a explosão, a queda, o desabamento, etc., apenas provocarem abalo moral, a reparação desse dano não ocorre ao abrigo da lei dos acidentes de trabalho. ${ }^{33}$ "

Com efeito, pensamos que se o abalo moral ou psíquico determinar incapacidade temporária ou permanente para o trabalho, deverá ter lugar a reparação infortunística, na exata medida dessa incapacidade. Já a vertente moral ou não patrimonial do dano fica excluída dessa tutela, a menos que o evento tenha resultado de atuação culposa do empregador.

CARLOS ALEGRE, define acidente de trabalho como o «acontecimento não intencionalmente provocado (ao menos pela vítima), de caráter anormale inesperado, gerador de consequências danosas no corpo ou na saúde, imputável ao trabalho, no exercício de uma atividade profissional, ou por causa dela, de que é vítima o trabalhador ${ }^{34}$.

Não menciona a causa externa ou exterior (no sentido de estranha à constituição orgânica da vítima) porque, como explica logo depois, a mesma suscita dúvidas sobre se tem de constituir uma ação direta sobre o corpo ou se pode ser indireta, se tem de ser clara, visível, evidente ou se pode atuar insidiosamente, de perceção imediata, se tem de atuar com violência, etc. E conclui que «nem o acontecimento exterior direto e visível, nem a violência são, hoje, critérios indispensáveis à caraterização do acidente ${ }^{35}$ ». Ou seja, apenas não considera a natureza externa quando interpretada no sentido de afastar causas indiretas, invisíveis e não violentas.

\footnotetext{
33 In Caderno de Acidentes de Trabalho e Doenças Profissionais, Coleção Formação Inicial, Centro de Estudos Judiciários, 2013, p. 35, disponível em: http://www.cej.mj.pt/cej/recursos/ebooks/trabalho/Caderno_Acidentes_trabalho.pdf?id=9

34 In Acidentes de Trabalho e Doenças Profissionais, p. 35.

35 Ob. cit., p. 36.
} 
Cremos que o pensamento de base está absolutamente correto, mas, perdoe-se-nos a ousadia, não tão bem expresso, pois o facto de uma causa poder ser indireta, invisível e não envolver violência (no sentido tradicional, de causar ferimentos corporais), não significa ou implica que a mesma não possa, e não deva, ser externa e, como tal, dar origem a um acidente de trabalho verdadeiro e próprio.

Por outro lado, e mais importante, a causa externa do acidente de trabalho está claramente subentendida na imputação do acontecimento ao trabalho que o mesmo Autor apresenta.

Ademais, e sem prejuízo de afastar a necessidade de um nexo de causalidade entre o trabalho e o evento danoso, atenta a consagração da teoria do risco económico, CARLOS ALEGRE não deixa de admitir a pertinência desse nexo com a relação laboral ao argumentar que se um trabalhador, na sequência de uma situação laboral crítica (despedimento, repreensão, punição, etc) desmaia, cai e sofre uma lesão, estamos perante um acidente de trabalho, mas não já se o desmaio se tiver devido a uma notícia alheia à relação laboral, concluindo, de forma elucidativa: "Trata-se, em última análise, de avaliar a relação de causalidade entre a causa exterior e a relação laboral ${ }^{36} »$ (destaque nosso).

A doutrina e a jurisprudência destacam, em regra, como elementos integradores do conceito de acidente de trabalho, os seguintes:

- elemento espacial: local de trabalho, no qual relevam quer o critério geográfico, quer o critério de autoridade (sujeição ao controlo direto ou indireto do empregador).

- elemento temporal: tempo de trabalho: período normal de trabalho e o que o precede em atos de preparação ou sucede, em atos com ele relacionados, e, ainda, as interrupções normais ou forçosas do trabalho.

- elemento causal: pressupõe um duplo nexo de causalidade ${ }^{37}$.

- entre o acidente e o dano físico, sendo que o mesmo se presume, se o dano ocorrer no local e no tempo de trabalho ${ }^{38} \mathrm{e}$

- entre o dano físico e o dano laboral, consubstanciado em incapacidade para o trabalho ou morte ${ }^{39}$.

$36 \quad$ Ob. cit., p. 37.

37 Cfr. RAMALHO,MARIA DO ROSÁRIO PALMA, ob. cit. p. 833.

38 Presunção consagrada no n. ${ }^{\circ} 1$ do art. ${ }^{\circ} 10^{\circ}$ da LAT.

39 Este nexo de causalidade não se encontra abrangido pela presunção legal do n. ${ }^{\circ} 1$ do art. ${ }^{0} 10^{\circ}$ da LAT., cfr. Ac. do STJ de 19/11/2008, Proc. ${ }^{\circ}$ 08S2466: «As referidas presunções não abrangem o nexo de causalidade entre as lesões corporais, perturbações funcionais ou doenças contraídas no acidente e a redução 
Há alguns doutrinadores, designadamente MARIA DO ROSÁRIO PALMA RAMALHO $^{40}$, que apontam ainda os seguintes dois:

- elemento subjetivo: trabalhador por conta de outrem de qualquer atividade, seja ou não explorada com fins lucrativos, cfr. n. ${ }^{\circ} 1$ do art. ${ }^{\circ} 3^{\circ}$ da LAT.

Entretanto, o art. $^{\circ} 4$ da Lei 7/2009, de 12 de Fevereiro, que aprova o Código do Trabalho, manda aplicar, com as necessárias adaptações, o regime dos acidentes de trabalho ao:

- praticante, aprendiz, estagiário e demais situações que devam considerar-se de formação profissional;

- administrador, diretor, gerente ou equiparado, sem contrato de trabalho, que seja remunerado por essa atividade;

- prestador de trabalho, sem subordinação jurídica, que desenvolve a sua atividade na dependência económica, nos termos do artigo 10. ${ }^{\circ}$ do Código do Trabalho ${ }^{41}$.

Ou seja, a lei visa proteger todos aqueles que estejam economicamente dependentes da sua prestação de trabalho a outrem.

- elemento do dano típico ${ }^{42}$ : só é objeto de reparação, um determinado tipo de dano, a saber, lesão corporal, perturbação funcional ou doença de que resulte incapacidade para o trabalho ou a morte. Por outro lado, apenas é reparada a vertente patrimonial; não são reparados danos não patrimoniais.

A questão que se coloca e que nos propomos aprofundar adiante é se, reunidos estes elementos, poderá, ipso facto, considerar-se que se trata de um acidente de trabalho.

da capacidade de trabalho ou de ganho, ou a morte da vítima, sendo a sua demonstração um ónus do sinistrado ou seus beneficiários.»

40 0b. cit., p. 828 e ss.

41 «As normas legais respeitantes a direitos de personalidade, igualdade e não discriminação e segurança e saúde no trabalho são aplicáveis a situações em que ocorra prestação de trabalho por uma pessoa a outra, sem subordinação jurídica, sempre que o prestador de trabalho deva considerar-se na dependência económica do beneficiário da actividade.»

42 MARTINEZ, PEDRO ROMANO refere que a delimitação do conceito de acidente de trabalho também é dada pelos danos, uma vez que os mesmos são típicos - ob. cit. p. 790. 


\section{A conexão do acidente com a prestação de trabalho ou com a relação laboral}

\section{a. A doutrina}

Regista-se na nossa doutrina uma corrente que considera que, estando preenchidos os requisitos acima indicados, nada mais é preciso para que se possa afirmar a verificação de um acidente de trabalho, por mais remota, ou mesmo inexistente, que seja a ligação do evento com o trabalho ou com a relação laboral.

LUÍS MENEZES LEITÃO defende que «A lei vem então exigir como pressuposto da reparação que a causa do dano esteja incluída dentro de uma certa zona de riscos. Esta zona é delimitada através de uma relação com a prestação de trabalho. Não se exige, de acordo com a nossa interpretação dos arts. $8^{\circ}$ e 9. ${ }^{\circ}$ da Lei 98/2009, um nexo de causalidade entre a prestação de trabalho e os danos. $O$ nexo de causalidade só tem de se verificar entre $o$ acidente e os danos. A relação entre o acidente e a prestação de trabalho é uma relação diferente, de natureza etiológica, que se estabelece através da ocorrência do acidente no momento em que o trabalhador pratica actos, de alguma forma ligados à sua prestação de trabalho ${ }^{43}$ ».

JÚLIO GOMES considera igualmente «que o acidente de trabalho não se reduz, no nosso ordenamento, ao acidente ocorrido na execução do trabalho, nem havendo sequer que exigir uma relação causal entre o acidente e essa mesma execução do trabalho» ${ }^{44}$, e conclui, logo depois, "Sendo suficiente que o acidente ocorra, na terminologia anglo-saxónica, por ocasião do trabalho, o acidente de trabalho pode consistir em um acidente ocorrido quando se presta socorro a terceiros ou, inclusive, numa situação em que o trabalhador é agredido ou vítima de uma "partida de mau gosto", quer o autor desse facto ilícito seja um colega, quer se trate de um terceiro estranho à relação laboral».

Trata-se da tese da ocasionalidade, a qual, essencialmente, considera os fatores espácio-temporais em detrimento dos fatores causais, como bem sintetiza CARLOS ALEGRE ${ }^{45}$.

Em nome da prevalência da teoria do risco económico sobre o risco profissional, e da dispensabilidade de um nexo causal entre a execução do trabalho e o acidente, envereda-se pela desnecessidade de uma ligação ou conexão do evento com o trabalho (latamente considerado) ou com a própria

\footnotetext{
43 Ob. cit., p. 434.

44 Ob. cit., p. 97.

45 Ob. cit., p. 49.
} 
relação laboral, bastando que o trabalhador sofra um evento danoso no local e tempo de trabalho ou nas situações de extensão do conceito, como é o caso do trajeto laboral, o que gera resultados muito questionáveis, quer do ponto de vista dogmático, quer, especialmente, do ponto de vista da justa reparação dos acidentes de trabalho, postulada na Constituição da República $^{46}$.

BERNANDO LOBO XAVIER entende que «...o evento deverá ter ligação ou conexão com a prestação de trabalho, ainda que esteja superada a exigência de uma relação de caráter causal entre o acidente e o trabalho. Essa conexão é estabelecida a partir de dois elementos, local e tempo de trabalho (só é acidente de trabalho o que se verifique no local e tempo de trabalho, entendendo-se, no entanto, largamente esses elementos - art. 8. ${ }^{\circ}$ da L n. ${ }^{\circ}$ 98/2009). Para além disso (art. 9. ${ }^{\circ}$ da L n. 98/2009), em certos casos, pode ser qualificado como acidente de trabalho um evento que ocorra fora da empresa (é o caso dos chamados acidentes in itinere) ou fora do tempo de trabalho ${ }^{47}$.

MARIA ADELAIDE DOMINGOS apresenta uma visão mais próxima da realidade, pois salienta que «em algumas situações o acidente ocorre no local e tempo de trabalho de acordo com as definições legais dessas duas coordenadas geográfico-temporais, mas o evento pode não ser qualificado como acidente de trabalho, bastando que a entidade empregadora demonstre que no momento do acidente o trabalhador se encontrava subtraído à sua autoridade. Contudo, na maioria das situações em que o evento ocorre no local e no tempo de trabalho, a não existência de acidente de trabalho resulta da falta de prova quanto à ocorrência de um nexo de causalidade adequada entre o acidente, a lesão e o dano ${ }^{48} »$.

VITOR RIBEIRO, numa perspetiva que nos parece adequada e atual, afirmava a necessidade um nexo causal relevante entre a relação de trabalho e o dano, como elemento integrador essencial do conceito de acidente de trabalho ${ }^{49}$.

PEDRO ROMANO MARTINEZ preconiza também a necessidade de uma conexão com o trabalho, referindo, a propósito das situações tipificadas como extensão do conceito de acidente de trabalho, "Verifica-se sempre uma conexão com o normal desenvolvimento da relação laboral, estando em causa

\footnotetext{
46 Cfr. alínea f) do n. ${ }^{0} 1$ do art. $^{\circ} 59^{\circ}$ : «Todos os trabalhadores, sem distinção de idade, sexo, raça, cidadania, território de origem, religião, convicções políticas ou ideológicas, têm direito (...) a assistência e justa reparação, quando vítimas de acidente de trabalho ou de doença profissional».

47 In Manual de Direito do Trabalho, Verbo, 2011, p. 958.

48 In Prontuário de Direito do Trabalho n. ${ }^{05} 76,77$ e 78, 2007, p. 48.

49 In Acidentes de Trabalho, Reflexões e Notas Práticas, Rei dos Livros, 1984, p. 207.
} 
infortúnios relacionados com o cumprimento de deveres ou o exercício de direitos decorrentes do contrato de trabalho ${ }^{50}$ ».

Consideramos que, efetivamente, um acidente de trabalho significa ou pressupõe que se está perante um evento que resulta do trabalho ou que com ele se relaciona; tem sempre de existir uma conexão com o trabalho prestado ou, mais latamente, com a relação laboral.

Não pode prescindir-se de uma conexão entre o acidente e a relação laboral e mesmo defender a sua desnecessidade, se do que se trata é de uma responsabilidade objetiva fundada no risco inerente a essa mesma relação laboral.

De resto, atente-se na solução que se encontra prevista para as doenças profissionais, reguladas no Capítulo III (artigos $93^{\circ}$ a $153^{\circ}$ ) da mesma LAT: são as que contam de uma lista (LDP) ${ }^{51}$, que apresenta, para lá do elenco das doenças que são consideradas, uma enumeração exemplificativa dos trabalhos suscetíveis de provocar cada uma delas, sendo, por isso, patente a exigência de uma ligação ao trabalho.

Por outro lado, a lesão corporal, a perturbação funcional ou a doença que não constem da LDP «são indemnizáveis desde que se prove serem consequência, necessária e direta, da atividade exercida e não representem normal desgaste do organismo ${ }^{52}$ ».

Exige-se, pois, clara e assumidamente, uma causalidade entre a atividade e a patologia, pelo que não se alcança o motivo de nos acidentes de trabalho, regulados pela mesma lei, não ser de admitir, segundo alguns, a exigência de um nexo de causalidade entre o acidente e a prestação de trabalho nem, sequer, entre o acidente e a relação laboral.

Na nossa opinião, o conceito de acidente de trabalho decompõe-se nos seguintes elementos caraterizadores e cumulativos:

- acidente: facto ou evento naturalístico cuja verificação é

- ocasional, imprevista

- súbita, repentina, de duração curta e limitada no tempo

- de origem externa à constituição da vítima

- lesiva ou danosa para a constituição da vítima

- de trabalho: ocorrido

50 Ob. cit. p. 798.

51 Publicada no Decreto Regulamentar n. ${ }^{\circ}$ 6/2001, de 5 de Maio, com as alterações introduzidas pelo Decreto Regulamentar n. ${ }^{\circ} 76 / 2007$, de 17 de Julho.

52 Cfr. n. ${ }^{\circ} 3$ do art. $^{\circ} 283^{\circ}$ do Código do Trabalho e n. ${ }^{\circ} 2$ do art. $^{\circ} 94^{\circ}$ da LAT. $^{2}$ 
- no local de trabalho

- no tempo de trabalho e

- verificando-se:

- um nexo de causalidade entre:

- o trabalho ou a relação laboral e o evento

- o evento e a lesão

- a lesão e a incapacidade ou a morte

\section{b. A jurisprudência}

Vejamos o modo como a nossa jurisprudência tem vindo a abordar esta matéria.

O conceito de acidente de trabalho é um tema que tem suscitado muita litigância ${ }^{53}$, sendo, por conseguinte, abundante e diversificada a jurisprudência que versa sobre o mesmo. Referiremos algumas decisões dos nossos tribunais superiores que consideramos especialmente relevantes:

- Acórdão do Supremo Tribunal de Justiça de 23/06/1999, Proc. ${ }^{0}$ 99S96:

"1-Para que se verifique a existência de um acidente de trabalho é necessária uma relação entre o trabalho e o acidente.

2-Ocorrendo o acidente no local e tempo de trabalho, presume-se aquela relação, competindo à entidade responsável ilidi-la.»(destaque nosso).

- Acórdão do Supremo Tribunal de Justiça de 20/10/1999, Proc. ${ }^{0}$ 99S183:

"I - Se o trabalhador foi vítima de homicídio consumado, com dolo directo, devido a desinteligências entre ele e o homicida totalmente estranhas à relação laboral, não existe qualquer nexo de causalidade entre o evento que determinou a morte do trabalhador e a sua relação laboral.

II - A circunstância do homicídio ter ocorrido no percurso que a vítima era obrigada a efectuar para se dirigir ao seu local de trabalho não é suficiente para se concluir pela existência de um acidente "in itinere"».

53 Estima-se que os acidentes de trabalho representam cerca de metade dos processos submetidos à apreciação dos tribunais do trabalho, cfr. MONTEIRO, J0Ã0, Fase Conciliatória do Processo para a Efetivação de Direitos Resultantes de Acidente de Trabalho - Enquadramento e Tramitação, in Prontuário de Direito do Trabalho, n. ${ }^{\circ}$ 87, p. 136. 
- Acórdão do Tribunal da Relação de Lisboa de 22/06/2005 - Proc. ${ }^{0}$ 107555/2004-4:

"Tendo o acidente que consistiu numa agressão de um terceiro ocorrida à saída da casa do trabalhador quando este se dirigia a pé para o estabelecimento onde trabalhava e onde ia entrar 30 minutos depois, deve entender-se que se deu no percurso normal efectuado e no período de tempo habitualmente gasto na ida da sua residência para o local de trabalho devendo classificar-se como acidente de trajecto nos termos do $n^{\circ} 2$ do art. $6^{\circ}$ do DL 143/99 de 30.04.»

- Acórdão do Supremo Tribunal de Justiça de 28/03/2007, Proc. ${ }^{0}$ 06S3957:

«1. A noção de acidente de trabalho reconduz-se a um acontecimento súbito, de verificação inesperada e origem externa, que provoca directa ou indirectamente lesão corporal, perturbação funcional ou doença de que resulte a morte ou redução na capacidade de trabalho ou de ganho ou a morte do trabalhador, encontrando-se este no local e no tempo de trabalho, ou nas situações em que é consagrada a extensão do conceito de acidente de trabalho.

2. No dominio da LAT de 1997, para que se qualifique um acidente in itinere como acidente de trabalho basta que ocorra no trajecto normalmente utilizado de ida e regresso para e do local de trabalho e durante o período ininterrupto habitualmente gasto pelo trabalhador, mesmo quando esse trajecto tenha sofrido interrupções ou desvios determinados pela satisfação de necessidades atendiveis do trabalhador, bem como por motivo de força maior ou por caso fortuito.

3. A circunstância do acidente de trabalho ter resultado de um roubo por esticão perpetrado por terceiro, quando a trabalhadora regressava ao seu domicílio, após ter terminado o trabalho, a pé e pelo trajecto habitualmente utilizado, não exclui o direito à sua reparação»(destaque nosso).

- Acórdão do Tribunal da Relação do Porto de 28/05/2007, Proc. ${ }^{0} 0711446$ :

«Não configura um acidente de trabalho indemnizável a situação em que a trabalhadora, ao sair do seu local de trabalho quando caminhava na rampa que liga o edifício à via pública foi atingida por um insecto no glóbulo ocular esquerdo, dado que tal acidente, embora com uma relação espácio - temporal com o trabalho, resultou de um caso de força maior e 
59 o conceito de acidente de trabalho

Conexão com a relação laboral

que não corresponde a qualquer risco criado ou agravado pelas condições de trabalho ${ }^{54}$ ».

- Acórdão do Tribunal da Relação de Coimbra de 31/05/2007, Proc. ${ }^{0}$ 907/04.6TTVIS.C1:

"No domínio da atual LAT (Lei 100/97, de 13 de Setembro), para que se considere um dado acidente como de trabalho, basta que o evento ocorra no trajeto normalmente utilizado e durante o período ininterrupto habitualmente gasto pelo trabalhador».

- Acórdão do Tribunal da Relação de Lisboa de 10/10/2007, Proc. ${ }^{0}$ 5705/2007-4:

«1. Acidente é todo o acontecimento ou evento súbito, violento, inesperado e de ordem exterior ao próprio lesado, ao contrário da doença profissional que pressupõe uma causa lenta, insidiosa e progressiva ou uma actuação continuada ou repetida de um agente, também "violento" e exterior ao próprio doente.

2. O acidente de trabalho é constituido por uma cadeia de factos em que cada um dos respectivos elos devem estar entre si sucessivamente interligados por um nexo causal: o evento súbito deve estar relacionado com a relação de trabalho; a lesão, perturbação ou doença, deve resultar daquele evento; $e$, finalmente, a morte ou a incapacidade para o trabalho deverão resultar da lesão, perturbação funcional ou doença.

3. O enfarte agudo do miocárdio sofrido por um trabalhador no local e tempo de trabalho, que the provoca a morte, presume-se, até prova em contrário, consequência de acidente de trabalho.

4. Essa presunção ficará, no entanto, ilidida se a entidade empregadora provar que não ocorreu qualquer evento súbito, de natureza exógena, no local e tempo de trabalho e que a vítima sofria de aterosclerose coronária que the determinou o referido enfarte do miocárdio.

54 Este aresto afasta tanto o entendimento de que um evento no local e no tempo de trabalho é um acidente de trabalho, por a verificação dos dois elementos fazer presumir a ocorrência de um acidente de trabalho, como o entendimento de que tem de se provar um nexo de causalidade entre o acidente e o trabalho; adota, ao invés, o entendimento segundo o qual, para lá da verificação dos elementos espacial e temporal, tem de se verificar uma certa relação entre o trabalho e o acidente, não se exigindo um nexo de causalidade entre ambos. Assim, se a origem do acidente tem uma ligação com o trabalho apenas no que respeita aos seus elementos temporal e espacial, não se está perante um acidente de trabalho. 
5. Mesmo que os beneficiários da vítima conseguissem demonstrar, tal como alegaram, que o trabalho na empresa e as condições em que era prestado esse trabalho, causavam à vitima stress profissional e que este determinou o aparecimento e o desenvolvimento da aterosclerose coronária que the causou o enfarte do miocárdio, nunca se poderia concluir pela existência de um acidente de trabalho, mas sim pela existência de uma doença profissional, por cujos danos seria responsável a CNPRP e não as recorridas» (destaque nosso).

- Acórdão do Supremo Tribunal de Justiça de 2/04/2008, Proc. ${ }^{0}$ 08S529:

«1. Em princípio, o acidente ocorrido durante a execução de um serviço determinado pelo empregador, mas emergente de acto da vida corrente do trabalhador, em que este tenha recuperado a sua independência em relação à missão profissional, não é qualificável como acidente de trabalho.

2. Tendo o acidente ocorrido no interior da casa de banho do quarto da estalagem onde o trabalhador se encontrava hospedado, momentos após ter tomado banho, não estão reunidos os pressupostos para que se possa qualificar o sinistro como um acidente de trabalho, uma vez que o mesmo não ocorreu no local do trabalho, nem no tempo de trabalho, revelando-se antes como um acontecimento pertinente à vida pessoal do trabalhador, estranho ao cumprimento da missão profissional.

3. Não releva a circunstância de ter sido guardado material de apoio logístico do secretariado da direcção, no quarto atribuído ao trabalhador, porquanto o acidente não resultou da execução da missão profissional determinada pelo empregador, nem ocorreu em tempo em que se manifestasse a autoridade patronal.

4. Acresce que não se provou que as concretas condições de alojamento atribuídas ao sinistrado tenham agravado o risco genérico que impende sobre a generalidade das pessoas quando procedem à sua higiene pessoal».

- Acórdão do Supremo Tribunal de Justiça de 5/11/2008, Proc. ${ }^{0}$ 08S2588:

"1. Não é de trabalho, o acidente de viação ocorrido quando o sinistrado, devidamente autorizado pela sua entidade empregadora, havia interrompido a prestação da sua actividade e abandonado o local de trabalho, para ir buscar o filho ao infantário e regressar com ele ao local de trabalho, a fim de ai continuar a exercer as suas funções profissionais. 
2. A tarefa que o sinistrado se propunha realizar (ir buscar o filho ao infantário, o que não chegou a fazer porque o acidente ocorreu quando ele se dirigia para o infantário) não tem a menor ligação com a actividade profissional que subordinadamente prestava à sua entidade empregadora; trata-se, antes, de uma tarefa de natureza estritamente pessoal e familiar que se prende, exclusivamente, com os actos da vida corrente do sinistrado $e$ que, por isso, é absolutamente alheia a qualquer missão ou função de carácter profissional.

3. A autorização dada pela entidade empregadora explica-se e justifica-se pelo facto de o sinistrado se encontrar dentro do seu periodo de trabalho, mas não altera a natureza privada da deslocação em questão, não podendo, por isso, a mesma ser qualificada de serviço, para efeitos dos disposto na alinea f) do $n .^{\circ} 2$ do art. ${ }^{\circ}$ 6. ${ }^{\circ}$ da LAT» (destaque nosso).

- Acórdão do Tribunal da Relação de Lisboa de 20/05/2009, Proc. ${ }^{0}$ 1014/03.4TTALM.1.L1-4:

«I-Do confronto do art. $2^{\circ} n^{\circ}$ s e 2 e art. $6^{\circ}, n^{\circ} 1$ da LAT, resulta que só pode qualificar-se como acidente de trabalho aquele em que concorram, cumulativamente, os seguintes pressupostos: uma relação de trabalho de que o sinistrado é parte; ocorrência, no tempo e local de trabalho, de um evento em sentido naturalístico (queda, corte, esmagamento, pancada, soterramento, etc.); que desse evento resulte lesão, perturbação funcional ou doença; de que provenha redução da capacidade de trabalho ou a morte do sinistrado; nexo de causalidade entre o evento e as lesões, bem como entre estas e a redução da capacidade de trabalho ou a morte.

II - A paragem cardio-respiratória não constitui uma causa de morte sendo, antes, a sua manifestação ou evidência. Não se tendo apurado a causa que levou à morte, não pode determinar-se quando é que essa causa ocorreu, o que a provocou, ou se ela teve, ou não, alguma relação com as funções laborais do sinistrado.

III - O art. $6^{\circ} n^{\circ} 5$ da LAT e o art. $7^{\circ}$, no 1 do DL $n^{\circ}$ 143/99 de 30/04, não estabelecem duas diversas presunções, mas uma só. O primeiro daqueles preceitos estabelece a presunção de nexo entre as lesões e o acidente e o segundo, no mero desenvolvimento daquela norma da LAT, clarifica que o reconhecimento das lesões a seguir ao acidente, deve ser feito no local e no tempo de trabalho.

$I V$ - Tal presunção só se refere ao nexo entre o acidente e a lesão e não ao nexo entre a lesão e a morte. Assim, em caso de morte, mesmo verificando-se aquela presunção de que as lesões são consequência do acidente, é aos 
beneficiários que compete alegar a provar, quer o evento lesivo (o acidente enquanto acontecimento imprevisto e exterior à pessoa da vítima), quer o nexo de causalidade entre as lesões e a morte» (destaque nosso).

- Acórdão do Supremo Tribunal de Justiça de 17/12/2009, Proc. ${ }^{0}$ 455/04.4TTLMG.S1:

«I - A responsabilidade do empregador relativamente aos acidentes de trabalho sofridos pelos seus trabalhadores não assenta no chamado risco profissional, mas sim no risco económico ou de autoridade.

II - É a teoria do risco económico ou de autoridade que está subjacente ao conceito de acidente de trabalho contido no art. ${ }^{\circ} 6^{\circ}$ da Lei n. ${ }^{\circ}$ 100/97, de 13-9.

III - O conceito de acidente de trabalho contido naquele normativo não exige a existência de um nexo de causalidade entre o acidente e a prestação de trabalho propriamente dita; apenas se exige um nexo de causalidade entre o acidente e a relação laboral.

$I V$ - Estando provado que ocorreu no local e no tempo de trabalho, deve ser considerado como sendo de trabalho o acidente de que resultou a morte do trabalhador, por asfixia provocada por dióxido de carbono existente no fundo de um silo de bagaço, quando ao descer para tentar salvar um menor que aí tinha ido buscar uma bola e que ficara inanimado devido ao dito gás» (destaque nosso).

- Acórdão do Supremo Tribunal de Justiça de 14/04/2010, Proc. ${ }^{0}$ 459/05.0TTVCT.S1:

«I - O conceito de acidente de trabalho é fornecido pelo art. ${ }^{\circ} 6 .^{\circ}$ da Lei $n .^{\circ}$ 100/97, de 13 de Setembro, sendo definido como aquele que se verifique no local e no tempo de trabalho e produza direta ou indiretamente lesão corporal, perturbação funcional ou doença de que resulte a redução na capacidade de trabalho ou de ganho ou a morte.

II - A caraterização de um acidente de trabalho pressupõe, assim, a verificação cumulativa de três elementos: um elemento espacial (em regra, o local de trabalho); um elemento temporal (correspondente, por norma, ao tempo de trabalho); um elemento causal (nexo de causa e efeito entre o evento e a lesão, perturbação funcional ou doença, por um lado, e entre estas situações e a redução da capacidade de trabalho ou de ganho ou a morte).

III - Porém, a montante dessa verificação cumulativa de pressupostos torna-se imperioso, desde logo, que o evento possa ser havido como "acidente", o que exige a sua produção ocasional, súbita e com origem externa. 
IV - Na interpretação do disposto no art. $6 .^{\circ}$, ns. $^{\circ} 5$ e 6, da Lei n..$^{\circ}$ 100/97, de 13 de Setembro, e do disposto no art. 7. ${ }^{\circ}$ do DL n. ${ }^{\circ}$ 143/99, de 30 de Abril, tem este Supremo Tribunal seguido um entendimento segundo o qual se está perante uma única - e a mesma - presunção, que é de natureza ilidivel e tem o seguinte alcance: a mera verificação do condicionalismo enunciado nos sobreditos preceitos demonstra a existência de nexo causal entre o acidente e a lesão, dispensando o beneficiário da sua prova efetiva, mas deixa em aberto a prova - necessariamente precedente e subordinada às regras gerais - de que o evento infortunistico configura "acidente de trabalho".

$V$ - Assim, a prova de que a trabalhadora foi encontrada sem vida, durante o seu horário de trabalho, na exploração onde exercia a sua atividade profissional e que a sua morte resultou da ingestão de organofosforados não é suficiente para se concluir pela verificação de um acidente de trabalho, pois que se ignoram, em absoluto, as circunstâncias em que tal ingestão se produziu».

- Acórdão do Tribunal da Relação de Lisboa de 19/10/2011, Proc. ${ }^{0}$ 128/8.9TBHRT.L1:

«1. Não é acidente de trabalho a morte da sinistrada por asfixia, no local e tempo de trabalho, pois resultou provado que a lesão que causou a morte à trabalhadora - asfixia - foi provocada por uma pastilha elástica encontrada na sua orofaringe que mastigava e que, inadvertidamente, engoliu, pelo que não foi algo exterior à vítima com ligações ao trabalho prestado que the provocou a morte.

2. A presunção a que alude o art. $^{\circ} 6$ n. ${ }^{\circ} 5$ da Lei 100/97, e o disposto no art. $^{\circ} 7$ do DL $n^{\circ}$ 143/99 de 30 de Abril, demonstra a existência de nexo causal entre o acidente e a lesão, dispensando o beneficiário dessa prova efectiva, mas não da prova de que o evento infortunístico configura um acidente de trabalho. Com efeito, saber se o evento é, ou não, um acidente, coloca-se a montante da problemática do nexo causal entre o acidente e a lesão, a que respeita a presunção estabelecida nos dispositivos referidos».

- Acórdão do Supremo Tribunal de Justiça de 26/10/2011, Proc. ${ }^{0}$ 154/06.2TTCTB.S1:

«I - Os acidentes que se verifiquem no trajecto normalmente utilizado pelo trabalhador e durante o periodo de tempo habitualmente gasto entre a sua residência habitual ou ocasional e o local de trabalho, são qualificados como acidentes de trabalho indemnizáveis, conforme resulta dos artigos $6^{\circ}$, 
$n^{\circ}$ 2, alínea a) da Lei 100/97 de 13 de Setembro e 6 $6^{\circ} n^{\circ} 2$ alínea a) do $D L n^{\circ}$ 143/99 de 30 de Abril.

II - É necessário no entanto, que exista uma ligação ao trabalho.

III - Deixa de existir tal ligação se o sinistrado, tendo terminado o trabalho ao meio-dia, só iniciou a viagem de regresso à sua residência ocasional cerca de quatro horas depois de ter deixado de trabalhar.

$I V$ - Por isso, não se pode qualificar o acidente por si sofrido cerca das 17 horas e 50 minutos, quando se dirigia no IP 8 em direcção ao Fundão, onde ia passar o fim-de-semana, como um acidente de trabalho in itinere» (destaque nosso).

- Acórdão do Supremo Tribunal de Justiça de 30/05/2012, Proc. ${ }^{0}$ 159/05.0TTPRT.P1.S1:

«I - O acidente de trabalho pressupõe uma cadeia de factos, em que cada um dos relativos elos está interligado por um nexo causal. Assim, o evento naturalístico que ele pressupõe há-de resultar duma relação de trabalho; a lesão corporal, perturbação funcional ou doença tem de resultar desse evento; e a morte ou a redução na capacidade de trabalho ou de ganho devem ter por causa a lesão corporal, perturbação funcional ou a doença.

II - Contudo, o acidente de trabalho em termos naturalisticos pode não ser instantâneo nem violento.

III - Deve considerar-se como acidente de trabalho o acontecimento anormal, de duração limitada, de que resultou uma lesão na saúde da trabalhadora, consubstanciada numa alteração do seu equilíbrio psíquico, com graves sequelas daí resultantes, que tendo ocorrido no tempo e no local de trabalho, preenche os requisitos exigidos pelo art. $6 .^{\circ}, n .^{\circ} 1 \mathrm{da} L A T$ » (destaque nosso).

- Acórdão do Tribunal da Relação de Lisboa de 23/10/2013, Proc. ${ }^{0}$ 291/11.1TTVFX.L1-4:

"I - Nos termos do art. 8. ${ }^{\circ}$ da Lei 98/2009 de 4 de Setembro, considera-se acidente de trabalho aquele que se verifique no local e tempo de trabalho e produza directa ou indirectamente lesão corporal, perturbação funcional ou doença de que resulte redução na capacidade de trabalho ou de ganho ou a morte.

II - O conceito de acidente de trabalho encontra-se em permanente actualização, questionando-se o que se deve entender por facto, evento, ou acontecimento externo, causador da lesão.

III - Aceita-se, actualmente, que nem o acontecimento exterior, directo e visível nem a violência, são critérios indispensáveis à caracterização do acidente. 
IV - É, pois, de considerar preenchido o conceito de acidente de trabalho, se se provou que no trajecto normalmente utilizado e durante o periodo tempo habitualmente gasto pela trabalhadora entre a sua residência ocasional e as instalações que constituem o seu local de trabalho, a trabalhadora sofreu uma tontura, tendo caído no pavimento, aí se estatelando, em consequência do que fracturou a tacícula radial do cotovelo direito, o que the determinou incapacidade temporária absoluta no período de 15.01.2011 a 04.07.2011, data em que teve alta, portadora de limitações na mobilidade do membro direito, particularmente na flexão e na extensão do cotovelo».

- Acórdão do Supremo Tribunal de Justiça de 16/09/2015, Proc. ${ }^{0}$ 112/09.5TBVP.L2.S1:

«I. A verificação de um acidente de trabalho demanda a presença de um elemento espacial (em regra, o local de trabalho) e de um elemento temporal (que em regra se reconduz ao tempo de trabalho) que expressem uma adequada conexão com a prestação laboral.

II. O acidente ocorrido no tempo e local do trabalho é considerado como de trabalho, seja qual for a causa, a menos que se demonstrem factos que claramente demonstrem que o acidente ocorreu à margem da autoridade patronal, ónus que pertence à entidade responsável.

III. A reparação dos danos emergentes dos acidentes de trabalho exige a demonstração de um duplo nexo causal: entre o acidente e o dano físico ou psíquico (a lesão, a perturbação funcional, a doença ou a morte); e entre este e o dano laboral (a redução ou a exclusão da capacidade de trabalho ou de ganho do trabalhador)".

IV. A presunção a que alude o art. $7^{\circ}$, n. ${ }^{\circ} 1$, DL 143/99, de 30/4, tem apenas o alcance de libertar os sinistrados ou os seus beneficiários da prova do nexo de causalidade entre o acidente e o dano físico ou psíquico reconhecido na sequência do evento infortunístico, não os libertando, todavia, do ónus de provar a verificação do próprio evento causador das lesões.

V. A mesma presunção também não abrange a segunda das relações de causalidade mencionadas em supra $n .^{\circ}$ III, incumbindo ao sinistrado ou seus beneficiários a sua demonstração.

VI. É de afirmar a existência de um acidente de trabalho quando resulta demonstrado que a sinistrada, no local e no tempo trabalho, sofreu traumatismo cranioencefálico provocado por pancada ou choque em superfície dura, enquanto desenvolvia a sua atividade profissional de empregada doméstica, traumatismo no qual radica a IPP fixada nos autos»(destaque nosso). 
Alguns destes arestos (Ac. do T.R. de Lisboa de 22/06/2005,Ac. do STJ de 28/03/2007 e Ac. do T.R. de Coimbra de 31/05/2007) encerram o entendimento de que no local e tempo de trabalho, ou nas situações de extensão do conceito, um acidente será forçosamente acidente de trabalho, enveredando pela tese da ocasionalidade.

Por seu turno, os demais procuram, para lá da verificação desses requisitos, aquilatar ainda se o evento ocorrido naquelas circunstâncias reveste alguma causalidade ou conexão com o trabalho ou com a relação laboral, numa posição mais próxima da tese da causalidade.

\section{i. Análise detalhada de dois acórdãos}

Analisamos de seguida mais detidamente o Acórdão do Tribunal da Relação de Lisboa de 19/10/2011, Proc. ${ }^{\circ}$ 128/8.9TBHRT.L1, cujo sumário acima se transcreveu, porquanto aborda de forma exemplar a temática dos acidentes de trabalho, apresentando uma delimitação do conceito de acidente de trabalho que importa reter, já que faz adequado uso dos elementos que integram o respetivo conceito.

Da matéria de facto provada no caso objeto do mesmo acórdão (caso da pastilha elástica), destaca-se a seguinte:

«1. C faleceu no dia 01 de Fevereiro de 2008, no estado de casada com o A., A.

3. À data do falecimento C era trabalhadora da Agência de Viagens D, SA, (...), com a categoria profissional de Chefe de Secção.

6. No dia 1 de Fevereiro de 2008, quando $C$ se encontrava no seu local de trabalho, foi encontrada, já depois do horário normal, no estado de cadáver.

7. Quando os seus colegas saíram da agência, C estava viva e sem problemas e não denotava quaisquer sinais de doença.

9. C trabalhava frequentemente para além do seu horário de trabalho, que tinha início às 09.00 horas e terminava às 18.00 horas, com intervalo para almoço entre as 12.30 e as 14.00 horas.

11. Quando ocorreu falecimento, $C$ tinha acabado o trabalho e preparava-se para sair da agência de viagens.

12. A falecida executava tarefas de processamento de documentos e organizava o trabalho realizado durante o dia, o que fazia frequentemente após o horário normal de trabalho.

13. O mencionado em 12 sucedia com o conhecimento dos colegas e da própria entidade patronal. 
14. Após ter sido encontrada no chão, C foi de imediato transportada ao Hospital da Horta onde the foram feitas manobras cardio-respiratórias sem sucesso.

15. A falecida tinha uma pastilha elástica na orofaringe.

16. O cadáver de $C$ apresentava cianose no pescoço e cabeça, bem como congestão visceral generalizada, sufusões sanguíneas subpleurais e subpericárdicas e fluidez sanguínea.

17. Os sinais mencionados em 16 são sinais inespecíficos de asfixia.

18. A pastilha elástica encontrada na orofaringe da falecida foi causa da sua asfixia.

19. Não foi identificada qualquer outra causa que justifique a morte de $C$.

20. As funções que haviam sido cometidas a $C$ não incluíam especiais esforços físicos que a afectassem em termos cardio-respiratórios nem eram, em si, perigosas, sendo aquela funcionária de escritório, lidando apenas com questões administrativas e de mero expediente» (destaques nossos).

Deste acervo de factos provados, salienta-se que a vítima:

- estava no seu local de trabalho,

- tinha acabado o trabalho e preparava-se para sair e

- morreu por asfixia, causada por uma pastilha elástica.

O acórdão começa por evocar a noção de acidente de trabalho, destacando como seus elementos "a existência de um acidente verificado no local e tempo do trabalho que cause, directa ou indirectamente lesão corporal, perturbação funcional ou doença e que delas resulte a morte ou a redução na capacidade de trabalho ou ganho», para de seguida concluir pela necessidade de se verificar «um nexo de causalidade entre a relação de trabalho e o facto naturalístico, entre este e a lesão corporal, perturbação funcional ou doença, e entre estas e a morte ou a redução da capacidade de ganho».

Depois aborda a presunção legal de que a lesão constatada no local e no tempo de trabalho é, até prova em contrário, consequência de acidente de trabalho, para, mais adiante, na esteira do entendimento do STJ, considerar que a mera verificação do condicionalismo enunciado nos preceitos que consagram essa presunção ${ }^{55}$, demonstra a existência de nexo causal entre o acidente e a lesão, dispensando a sua prova efetiva, mas não dispensa o ónus de provar a verificação do próprio evento.

Por conseguinte, segundo este douto entendimento, tais presunções, «são de todo alheias à ocorrência do próprio acidente, enquanto tal, reportando-se o seu sentido útil em exclusivo aos pressupostos daquele nexo de causalidade».

55 N. ${ }^{\circ} 5$ do art. ${ }^{\circ} 6^{\circ}$ da Lei 100/97, de 13 de Setembro, e n. ${ }^{\circ} 1$ do art. ${ }^{\circ} 7^{\circ}$ do D. L. 143/99, de 30 de Abril. Atualmente, esta matéria encontra-se regulada no art. ${ }^{\circ} 10^{\circ}$ da Lei 98/2009, de 4 de Setembro. 
Cita, ainda, PEDRO ROMANO MARTINEZ, para quem "Não se trata de uma presunção da existência do acidente, mas antes uma presunção de que existe nexo causal entre o acidente e a lesão ocorrida».

E, seguindo de perto o Acórdão do STJ de 14/04/2010, cujo sumário acima se transcreveu, a Desembargadora Relatora ${ }^{56}$ consigna que «a simples constatação da morte da trabalhadora no local e tempo de trabalho não faz presumir a existência de um acidente de trabalho, não dispensando o beneficiário da sua prova efectiva - necessariamente precedente e subordinada às regras gerais - de que o evento infortunístico configura um acidente de trabalho, pelo que esta questão, saber se é, ou não, um acidente, coloca-se a montante da problemática do nexo causal entre o acidente e a lesão, a que respeita a presunção estabelecida nos dispositivos referidos».

Mais considera que "para que um determinado evento possa ser considerado acidente de trabalho, tem, antes de mais, de se tratar de um acidente, ou seja, de um acontecimento ou evento de carácter súbito, na medida em que inesperado na vida do trabalhador por conta de outrem ou equiparado, enquanto no exercício da sua actividade profissional ou por causa dela, acontecimento que seja, directa ou indirectamente, gerador de consequências danosas no corpo ou na saúde do trabalhador...» (destaque nosso).

Por outro lado, é particularmente assinalável a asserção de que, por virtude de se estar no âmbito da responsabilidade objetiva, emergente de acidente de trabalho, a qual se funda no risco que é inerente ao exercício de toda e qualquer atividade profissional, fazendo recair sobre o empregador, que com ela beneficia, a obrigação de reparar os danos correspondentes, assume especial relevância a delimitação do conceito de acidente de trabalho a um acontecimento externo, com vista a excluir do âmbito dos acidentes de trabalho situações em que a lesão que provocou a incapacidade ou morte não se relaciona com a atividade desenvolvida sob a autoridade de outrem, ou seja, nas situações em que o dano decorre de uma realidade que apenas diz respeito ao trabalhador, a denominada causa endógena, e que nada tem a ver com a atividade desenvolvida.

Considera, portanto, que no caso subjudice, se verifica tanto o elemento temporal como o elemento espacial, mas soçobra o elemento causal, pois a lesão que provocou a morte à infeliz trabalhadora não ocorreu por causa do trabalho que esta desenvolvia ao serviço da entidade empregadora, algo exterior à mesma com ligações ao trabalho prestado: a morte proveio de asfixia provocada por uma pastilha elástica.

56 Desembargadora PAULA SÁ FERNANDES. 
E conclui, lapidarmente, que «a acção da vítima - mascar a pastilha nada tem que ver com o trabalho desenvolvido ou por causa deste, mas apenas uma relação no que toca aos elementos espácio-temporais do trabalho».

Nem mesmo a argumentação de que a trabalhadora morreu asfixiada por ter ficado a trabalhar sozinha e que esse facto "potenciou" a sua morte, por não ter quem a ajudasse a expelir a pastilha que lhe provocou a asfixia, foi suficiente para estabelecer a necessária relação de causalidade, ou de conexão entre o evento e o trabalho, pois tratou-se de um ato voluntário da vítima - mascar a pastilha - imputável à vida corrente, e sem qualquer relação com a atividade desempenhada ao serviço do empregador, não correspondendo, por isso, a qualquer risco potenciado pela sua atividade profissional ou pelas suas condições de trabalho.

E decide, como não poderia deixar de ser, no sentido de que as lesões e o consequente óbito da sinistrada não tiveram origem em ocorrência qualificável como acidente de trabalho.

Um outro aresto que justifica uma análise mais detalhada é o Acórdão do Tribunal da Relação de Lisboa de 23/10/2013, cujo sumário também transcrevemos supra e do qual parece resultar uma adoção sem reservas da tese da ocasionalidade. No entanto, é um dos acórdãos que melhor apologia faz da tese da causalidade, como veremos.

$\mathrm{O}$ aresto versa sobre um evento que se pode resumir assim: a trabalhadora, quando se deslocava para o trabalho e após sair do autocarro que a transportou até à Gare do Oriente, em Lisboa, atravessava a via de trânsito e caiu no pavimento, aí se estatelando, em virtude de ter sofrido uma tontura. Em consequência dessa queda, sofreu traumatismo no cotovelo direito, fraturando a tacícula radial. Foi alegado, mas não provado, que a sinistrada padecia de síndrome vertiginoso, estando naquela data medicada com Betaserc e a tomar tal medicamento; apenas se provou que o mesmo pertence à classe dos anti vertiginosos, destinando-se a combater tonturas e desequilíbrios.

A Ilustre Desembargadora ${ }^{57}$ expendeu que "Como tem sido assinalado, pela nossa jurisprudência, a responsabilidade objectiva emergente de acidentes de trabalho baseia-se no risco que é inerente ao exercício de qualquer e toda a actividade profissional, recaindo sobre os empregadores, que com ela beneficiam, a obrigação de reparar os danos correspondentes. Deste modo, a menção a um acontecimento externo visa apenas excluir do âmbito dos acidentes de trabalho as situações em que a lesão que provocou a incapacidade ou morte não se relaciona com a actividade desenvolvida sob a autoridade de outrem, ou seja, os casos em que o dano decorre de uma realidade que apenas diz respeito ao

57 Isabel Tapadinhas 
trabalhador (causa endógena), que nada tem que ver com a actividade desenvolvida (Acs. desta Relação 10.11.2010, proc. 383/04.3TTGMR.L1, de 19.10.2011, proc. 128/8.9TBHRT.L1 e de 12.10.2011, proc. 282/09.2TTSNT.L1, www.dgsi.pt).

Acresce que para que o acidente se qualifique como de trabalho, entre outros elementos caracterizadores, é necessário que exista, como referia Vítor Ribeiro ob. cit., pág. 207), nexo causal relevante entre a relação de trabalho e o dano. E melhor especificando, noutro passo: razão por que esse "nexo causal" entre a relação de trabalho e a morte ou a incapacidade (...), deve, ele também, considerar-se como elemento integrador essencial do conceito legal de "acidente de trabalho".

$\boldsymbol{O}$ nexo de causalidade que deve existir entre o acidente e o trabalho é, pois, um dos elementos caracterizadores do acidente de trabalho, que não resulta expressamente da lei, mas que se contém no seu espírito.

Como ensinava Cruz de Carvalho ("Acidentes de Trabalho e Doenças Profissionais", $2^{a}$ ed., págs. 28 e 55), para a relevância de tal elemento já a Câmara Corporativa havia chamado a atenção, ao dar parecer sobre o projecto da proposta de Lei (depois Lei 2127), propondo se introduzisse no texto referência expressa a tal elemento, considerando-se como acidente de trabalho todo o evento que se verifique, no tempo e em consequência do trabalho.

À fórmula proposta pela Câmara Corporativa veio a apresentar-se uma outra, que se limitava a excluir da protecção legal os acontecimentos inteiramente estranhos à prestação de trabalho, alterando-se o texto inicial para todo o evento que se verifique no local e no tempo de trabalho, salvo quando a este inteiramente estranho.

Porém, no texto definitivo aprovado pela Assembleia Nacional não ficou a constar qualquer referência expressa àquele elemento caracterizador do acidente de trabalho. Ao que parece, por se considerar inútil. Mas sem razão, pois se deixou, mais uma vez, para a doutrina e para a jurisprudência, buscar, através de árduas construções teóricas, aquilo que, de modo claro e intuitivo, poderia resultar da lei.

Tal como sucede na lei Belga (Lei de 10 de Abril de 1971, sobre acidentes de trabalho), para qual, acidente de trabalho é todo o acidente que sobrevém a um trabalhador durante e por causa da execução do contrato e que produz uma lesão. Ou na lei Espanhola (Decreto de 22.6.56) para a qual o mesmo acidente é toda a lesão corporal que o trabalhador sofra na ocasião ou por consequência do trabalho que execute por conta alheia (Vitor Ribeiro, ob. cit. págs. 197 e 201).

Que o nexo de causalidade entre o acidente e o trabalho é imprescindivel para a caracterização do acidente é conclusão que a jurisprudência tem subscrito com inteira uniformidade, justificando a exigência daquele nexo de causalidade nos seguintes termos: funda-se a responsabilidade por acidentes 
de trabalho no risco da autoridade e no proveito económico que a entidade patronal tira da actividade pela qual é tornada responsável, e visando essa responsabilidade cobrir o risco do trabalho, necessariamente que lhe tem de imputar a existência de uma relação entre o acidente e o trabalho.

Ou seja, o acidente de trabalho pressupõe a ocorrência de um evento (nessa previsão geral, que é a que aqui está em causa, no local e durante o tempo de trabalho) e a verificação de uma cadeia de factos interligados por um nexo causal. Assim, a lesão corporal, perturbação funcional ou doença hão-de resultar desse evento; e a morte ou a redução da capacidade de trabalho ou de ganho devem ser causadas pela lesão corporal, perturbação funcional ou doença» (destaque nosso).

$\mathrm{O}$ aresto considera estar-se perante um acidente de trabalho por não se ter provado a causa da tontura, que, por sua vez, deu causa à lesão, designadamente por não se ter provado que teve origem na síndrome vertiginoso de que a sinistrada padecia e que por causa dele a mesma estava medicada com Betaserc.

É discutível, pois estando provado que a queda resultou de uma tontura, estar-se-á perante uma causa endógena, atinente ao organismo da pessoa e ao respetivo estado de saúde. De todo o modo, não se sabendo exatamente a causa da tontura, pode a mesma ter tido origem num fator externo, tanto mais que a sinistrada estava na via pública (calor, frio, inalação de gazes de escape, etc). E desconhecendo-se o que efetivamente deu causa ao evento, tem de funcionar a presunção de que se tratou de um acidente de trabalho, nos termos do art. ${ }^{\circ} 10^{\circ}$ da LAT.

Como vimos supra, numa parte da jurisprudência e da doutrina encontram-se entendimentos segundo os quais tudo o que acontece no local e no tempo de trabalho, ou em alguma das situações tipificadas como extensão do conceito, máxime no trajeto laboral - o que ainda é mais problemático, como adiante se procurará demonstrar - constitui acidente de trabalho, sem que se cure de saber mais nada, designadamente o que, de facto, esteve na causa do evento.

Afirma-se que o facto de o evento ocorrer no local e no tempo de trabalho é suficiente para assegurar a conexão com a prestação do trabalho, sendo dispensável a exigência da prova de qualquer nexo de causalidade.

Mas, não devendo exigir-se a verificação de um nexo de causalidade entre o acidente e a execução do trabalho, o que seria demasiado redutor do conceito, pois que o limitava ao risco estritamente profissional, deve provar-se, ao menos, um nexo de causalidade entre o acidente e a relação 
de trabalho, sob pena de conferir tutela legal a eventos que não a justificam, por serem totalmente alheios a essa relação.

A não ser assim, teremos eventos classificáveis como "acidentes de trabalhadores" ou como "acidentes no trabalho", porquanto acidentes de trabalho dificilmente serão.

É tão importante e imprescindível provar que houve um acidente, quanto provar que o mesmo foi de trabalho.

Entretanto, tal causalidade não pode ser meramente circunstancial, casual, ocasional ou aleatória; deve ser uma causalidade efetiva ou eficiente, sem a qual seria impossível ou, pelo menos, improvável, que o acidente ocorresse. Caso contrário, será sempre possível estabelecer uma ligação, por mais remota que seja, entre o evento e o trabalho. É uma mera questão de criatividade ${ }^{58}$.

Muito recentemente, o STJ, no acórdão de 16/09/2015, cujo sumário acima se transcreveu, veio afirmar que "Independentemente das querelas doutrinárias atinentes à sua exata delimitação, pode afirmar-se, grosso modo, que o acidente de trabalho consiste sempre num evento danoso que, entre outras características, apresenta determinada conexão com a prestação do trabalho» (destaque nosso).

Ora, háinúmeras situações que podem ocorrer, tanto no local de trabalho como nas situações de extensão do conceito, que não podem ser qualificadas como acidente de trabalho, porque não apresentam conexão com este, sendo totalmente alheias e independentes do fenómeno laboral.

\section{c. As agressões cometidas por terceiros}

Vejamos as agressões cometidas por terceiros sobre o trabalhador no trajeto laboral ou no seu local de trabalho, por motivos puramente pessoais, do foro da vida privada do trabalhador: desavenças familiares (partilhas, por exemplo), conflitos entre vizinhos, questões passionais, monetárias, políticas, religiosas, desportivas, etc.:

- o trabalhador que está a chegar a casa, vindo do trabalho, e o vizinho que mora no andar por baixo do seu, ao encontrá-lo nas escadas do prédio, agride-o por virtude do ruído que o mesmo alegadamente produz;

58 0corre-nos, a propósito, a participação de acidente de trabalho apresentada por um trabalhador independente, relativamente ao que descreveu como «um mau jeito ao pescoço, quando, sentado à mesa de um café, me voltei para cumprimentar uma cliente». 
- o trabalhador que no caminho para o trabalho encontra casualmente dois adeptos do clube rival, que o espancam por causa do jogo de futebol da véspera;

- a trabalhadora de uma loja de um centro comercial que, no seu local de trabalho, é alvejada com um tiro desferido pela dona da loja do lado, por ter descoberto que há um relacionamento amoroso entre aquela e o seu marido;

- a trabalhadora de uma lavandaria que é espancada pelo irmão, toxicodependente, com ela residente, que ali se dirigiu para a obrigar a dar-lhe dinheiro, no que já vinha insistindo há vários dias.

De acordo com a chamada tese da ocasionalidade, todos estes trabalhadores foram vítimas de um acidente de trabalho, pois, por um lado, estavam no trajeto laboral ou no local e tempo de trabalho e, por outro, não se verificou nenhuma das situações descaracterizadoras previstas na LAT!

No que especificamente respeita aos acidentes in itinere, defende-se a ideia de que, com a eliminação da exigência de um risco genérico agravado do trajeto ou de um risco específico do mesmo trajeto, operada pela Lei 100/97, passou a verificar-se uma tutela generalizada do risco in itinere.

Não obstante, a jurisprudência do STJ, expressa nos acórdãos de 23/06/1999 e de 20/10/1999, cujos sumários acima transcrevemos, apesar de respeitarem a eventos regulados pela Lei 2127, parece-nos totalmente válida.

No primeiro deles, o Desembargador relator ${ }^{59}$ refere impressivamente «necessário é que se verifique, pelo menos, uma relação entre o trabalho e o acidente, por forma a afastar as situações totalmente estranhas à actividade que o trabalhador está a prestar (como, v.g. uma agressão por motivos políticos, por ciúme)»(destaque nosso).

E mais recentemente, o mesmo STJ, no Ac. de 26/10/2011, Proc. ${ }^{\circ}$ 154/06.2TTCTB.S1, cujo sumário acima transcrevemos, evidenciou a necessidade de uma conexão com o trabalho no âmbito dos acidentes in itinere, ao afirmar categoricamente que é necessário que exista uma ligação ao trabalho.

Importa salientar que, mesmo CARLOSALEGRE, que se mostra próximo da tese da ocasionalidade, não deixa de referir lapidarmente «Em primeiro lugar, a relação entre o caminho e o trabalho apresenta um caráter laboral evidente e indissociável, excepto naqueles casos em que se quebre esse elo de ligação, por razões estranhas ao trabalho ${ }^{60} »$ (destaque nosso).

\footnotetext{
59 Almeida Devesa

60 0b. cit, p. 54.
} 
O facto de ter desaparecido a exigência de que o acidente fosse consequência de particular perigo do percurso normal ou de outras circunstâncias que agravassem o risco do mesmo percurso, não implica que tenha passado a ser acidente de trabalho tudo quanto de nocivo aconteça ao trabalhador no percurso laboral, nem significa que tal particular perigo ou especiais circunstâncias não devam ser consideradas, precisamente, para dar conteúdo à conexão que deve existir entre o evento e a relação laboral.

Do mesmo modo que o abandono da tese do risco profissional, que limitava o conceito de acidente de trabalho aos eventos resultantes da atividade laboral concretamente desenvolvida, não visou, e muito menos autorizou, considerar acidente de trabalho tudo quanto não resulte dessa atividade.

Há que não perder de vista que, para lá dos acidentes resultantes diretamente da prestação de trabalho, só passaram a ser considerados os acidentes filiáveis na situação de subordinação do trabalhador ao poder de autoridade do empregador, ou seja, conexos com a relação laboral e não tudo o mais que possa acontecer ao trabalhador no local e no tempo de trabalho.

Pois bem, é esse o critério que, com as devidas adaptações, tem de ser aplicado no âmbito dos acidentes in itinere: será acidente de trabalho todo o evento ocorrido no trajeto (o que, de resto, se presume, nos termos do $\mathrm{n}^{\circ} 1$ do art. $^{\circ} 10^{\circ}$ da LAT), exceto se resultante de causa alheia à relação laboral.

Todavia, posição oposta emerge do Acórdão do Supremo Tribunal de Justiça de 28/03/2007, Proc. ${ }^{\circ}$ 06S3957, a propósito do roubo por esticão. Embora nos pareça um caso discutível, propendemos a considerar que a qualificação como acidente de trabalho acaba por ser adequada, atendendo ao facto de que a trabalhadora tinha um horário no turno, que terminava às $22 \mathrm{~h}$, tendo o evento ocorrido cerca da $22 \mathrm{~h} 30$, numa zona quase desertificada à noite. Assim, esse horário obrigava-a a deambular pela rua a horas tardias, expondo-a a redobrados perigos, pelo que se verifica uma conexão entre o evento e a relação laboral.

O STJ entendeu no citado aresto que, para que se qualifique um acidente in itinere como acidente de trabalho, basta que o mesmo ocorra no trajeto normalmente utilizado de ida e regresso para e do local de trabalho e durante o período ininterrupto habitualmente gasto pelo trabalhador. $\mathrm{Ou}$ seja: tais circunstâncias, uma vez verificadas, assegurariam a conexão com o trabalho, entendimento que, salvo o devido respeito, não podemos sufragar, pois trata-se de meros requisitos formais, que só por si, não consubstanciam uma conexão com a prestação de trabalho, nem com a relação laboral.

A ocorrência do evento nessas circunstâncias não basta para estabelecer a referida conexão, da mesma forma que a ocorrência no local e tempo de trabalho também não basta, tendo de se verificar, adicionalmente, uma 
relação com o trabalho (ainda que latamente considerado), para permitir filtrar todas aquelas situações que nada têm a ver com o mesmo e apenas respeitam à vida particular do trabalhador.

Atente-se na manifesta ligação ao trabalho, ou à relação laboral, que é exigida no n. 2 do artigo 8. $^{\circ}$, ao definir local de trabalho como todo o lugar em que o trabalhador se encontra ou deva dirigir-se em virtude do seu trabalho e em que esteja, direta ou indiretamente, sujeito ao controlo do empregador e tempo de trabalho como, além do período normal de trabalho, o que precede o seu início, em atos de preparação ou com ele relacionados, e o que se lhe segue, em atos também com ele relacionados, e ainda as interrupções normais ou forçosas de trabalho.

Assim, a lei exige expressamente uma relação ou conexão com o trabalho para se considerar que o evento ocorre no local e no tempo de trabalho, pelo que seria incompreensível que a não exigisse relativamente aos eventos ocorridos fora dos mesmos, no âmbito das situações que prevê como extensão do conceito. No percurso, a pessoa não está ainda a trabalhar, mas está a deslocar-se para o trabalho, pelo que deve, naturalmente, beneficiar da proteção legal. Todavia, se o evento resulta de algo que nada tem a ver com o trabalho, essa proteção não tem razão de ser.

Por outro lado, relativamente aos eventos ocorridos nas demais situações de extensão do conceito, previstas no artigo $9 .^{\circ}$ da LAT, não se prescinde dessa conexão ${ }^{61}$.

O STJ, no aresto de 28/03/2007, na fundamentação de que a circunstância de o acidente de trabalho ter resultado de um roubo por esticão perpetrado por terceiro não exclui o direito à sua reparação, invoca o facto de na elaboração da Lei 2.127 não ter vingado a proposta que colocava na redação do conceito de acidente de trabalho a expressão "salvo quando a este (trabalho) inteiramente estranho".

Ora, a retirada do projeto da LAT da referida ressalva, semelhante, de resto à que vigora atualmente em Espanha, não pode ser entendida como um salvo-conduto para acolher no âmbito da tutela acidentária realidades a ela manifestamente alheias.

Não terá sido esse o propósito do legislador, mas apenas o de "arrumar" devidamente os temas, deixando de um lado o que integra o conceito pela positiva, numa perspetiva inclusiva e caraterizadora, e

61 DOMINGOS, MARIA ADELAIDE, ob. cit, p. 45, nota 17, a propósito dos serviços determinados pela entidade empregadora previstos no art. ${ }^{\circ} 6^{\circ} / 2$ / d) e e) da Lei 100/97, refere que «A determinação dos serviços pela entidade empregadora não significa cobertura imediata de todos os acidentes ocorridos no cumprimento da missão fora da empresa, importando averiguar se o acidente se enquadra num acto da vida profissional ou da vida privada do trabalhadon». Idem MARTINEZ,PEDRO ROMANO, ob. cit, p. 797 e ALEGRE,CARLOS, ob. cit, p. 46. 
do outro, aquilo que o delimita pela negativa, que o afasta da reparação ou descarateriza.

E, certamente, também não passava pela mente do legislador que no conceito de acidente de trabalho viessem a ser incluídas situações a ele totalmente estranhas, só porque ocorrem no local e no tempo de trabalho ou no trajeto laboral.

De resto, em boa verdade, a maioria da nossa jurisprudência, mesmo com a definição que acabou por ser consagrada, tem primado pelo afastamento do âmbito da tutela dos acidentes de trabalho de eventos que a ele não respeitam e lhe são estranhos.

O mencionado aresto do STJ, que decidiu bem e fez justiça, mas com uma fundamentação que não subscrevemos, tem, precisamente, sido aproveitado para defender a extensão do conceito de acidente de trabalho a crimes reconhecidamente alheios ao trabalho ou mesmo à relação laboral, caso calhe serem cometidos no trajeto laboral.

Leiam-se, a este propósito, as considerações de JÚLIO GOMES «No nosso sistema, em que no domínio dos acidentes de trajeto, a jurisprudência portuguesa tem reconhecido a existência de um acidente de trabalho indemnizável quando o trabalhador é vítima, por exemplo, de um roubo por esticão, parece-nos que seria algo paradoxal exigir, ao invés, para que uma agressão ocorrida no tempo e local de trabalho fosse um acidente de trabalho, a demonstração da sua conexão com a relação laboral. Aliás, importa não esquecer que mesmo crimes de que o trabalhador seja vítima no tempo e no local de trabalho, aparentemente não conexos com a sua qualidade de trabalhador e com a sua prestação, podem, ao menos, ter sido facilitados por essa qualidade. O conhecimento dos horários de trabalho e do local de trabalho da vítima, o contacto com a vítima no próprio local de trabalho, pode ter potenciado ou facilitado a agressão e ser tido em conta no plano do agressor ${ }^{62}$ ".

Salvo o devido respeito, o estabelecimento deste paralelismo constitui um alargamento excessivo do conceito de acidente de trabalho, que nem o princípio de proteção do trabalhador pode justificar, pois nenhum empregador deve ser responsabilizado por algo desta natureza que aconteça com um seu trabalhador.

Este aresto, relativo, pois, a uma agressão perpetrada por terceiro estranho à vítima não permite equiparação com as situações em que as agressões são perpetradas por terceiros relacionados com a vítima. Tal constitui uma assinalável diferença com as situações que vimos analisando: a origem da

62 Ob. cit. p. 100 a 102. 
agressão é equidistante relativamente à vítima e ao seu empregador, sendo ambos igualmente alheios à mesma, pelo que repugna menos a qualificação como acidente de trabalho, tanto mais que, no caso, essa agressão teve lugar de noite e num local desertificado àquela hora.

Se a agressão emerge de um conflito da vida privada da vítima, insere-se num risco que é da conta desta e nunca da do seu empregador, totalmente alheio ao mesmo. Não só ele não tem culpa - nem precisaria de a ter, é certo, pois trata-se de uma responsabilidade objetiva - como o evento não emerge da relação laboral que a vítima tem com ele, o que deve ser determinante para que a sua responsabilidade não seja convocada para reparar um evento destes.

Se o marido, no contexto de um divórcio litigioso, mata a mulher quando ela está a chegar à rua onde habita, vinda do trabalho, a vítima não é assassinada por ter ido trabalhar ou, simplesmente, por trabalhar. Se a mulher coloca veneno na comida que o marido leva na sua lancheira e este morre no seu local de trabalho, ao almoçar, não é seguramente por causa do trabalho ou da sua relação laboral, que ele morre.

Não é o trabalho ou a relação laboral que determinam o risco. Mais: qualquer trabalhador que se desloque de ou para o local de trabalho, está normalmente exposto ao risco de queda, atropelamento, assalto, etc, mas já não está, por esse facto, sujeito ao risco de ser assassinado pelo cônjuge.

De salientar que, curiosamente, mesmo quem defende a desnecessidade de um nexo causal ou de uma conexão entre a agressão e o trabalho ou a relação laboral, procura quase sempre lobrigar uma qualquer ligação, por mais ténue, remota ou virtual que seja com a relação laboral, de que é exemplo a alegação de o agressor poder utilizar o conhecimento que tem do horário e percurso laborais da vítima, para perpetrar o crime.

E é interessante verificar também que, apesar da defesa do não afastamento da reparação infortunística de agressões a trabalhadores por parte de terceiros por motivos estritamente pessoais e alheios ao trabalho, é apresentado um critério de sinal oposto no âmbito de outras matérias.

Assim sucede com JÚLIO GOMES, que relativamente às deslocações em missão profissional, considera que nem todo o tempo e toda a atividade do trabalhador deslocado se encontram tutelados, devendo ser excecionados os atos da vida privada. É o caso do trabalhador deslocado uns dias noutra cidade, onde trabalha durante o dia e aproveita o serão para ir ao cinema ou visitar uns amigos, sofrendo uma queda nesse contexto.

Este ilustre Autor defende "que mesmo durante o serviço ou "missão" haverá que distinguir entre o período em que o trabalhador está a executar esse 
mesmo serviço ou missão ou a realizar atos preparatórios ou complementares, dos momentos em que recupera a sua liberdade e a sua vida pessoal ${ }^{63}$ ".

O STJ também assim entendeu no Ac. de 2/04/2008, Proc. ${ }^{\circ} 08$ S529 (caso da queda da trabalhadora na casa de banho da estalagem onde pernoitava, por virtude de uma deslocação em missão profissional), fazendo uma nítida demarcação entre aquilo que tem ligações ao trabalho e aquilo que se prende com a vida pessoal e corrente de um trabalhador.

De igual modo, no que concerne a eventos ocorridos dentro do logradouro da residência do sinistrado quando este sai para o trabalho ou regressa do mesmo. Quer o citado Autor ${ }^{64}$, que a jurisprudência mais recente ${ }^{65}$,entendem que tais eventos não devem ser qualificados como acidentes de trabalho por ocorrerem num espaço privado do trabalhador, pelo mesmo exclusivamente controlado, designadamente em matéria de condições de segurança.

\section{i. 0 Direito internacional}

Na maior parte dos ordenamentos jurídicos, a agressão por razões inteiramente estranhas à relação laboral não é objeto de reparação no âmbito dos acidentes de trabalho.

Na Bélgica, o conceito de acidente de trabalho encontra-se no art..$^{\circ} 7^{\circ}$ da Lei de 10 Abril de 1971: "Pour l'application de la présente loi, est considéré comme accident du travail tout accident qui survient à un travailleur dans le cours et par le fait de l'exécution du contrat de louage de travail et qui produit une lésion», cumulando, pois, a ocasionalidade com a causalidade.

A esta norma foi acrescentado pelo art. ${ }^{\circ} 6^{\circ}$ da Lei de 21 de Dezembro de 2013 o seguinte parágrafo: "Est également considéré comme accident du travail, l'accident subi par le travailleur en dehors du cours de l'exécution du contrat, mais qui est causé par un tiers du fait de l'exécution du contrat » (destaque nosso).

Portanto, o acidente causado por um terceiro será acidente de trabalho quando tiver origem no contrato de trabalho.

63 0b. cit., p. 113.

64 0b. cit., p. 181: «0s acidentes ocorridos na própria residência do trabalhador não são tutelados, provavelmente, por se situarem numa esfera de risco do próprio trabalhador, num espaço por este controlado e a cujos perigos sempre se exporia, mesmo sem o trabalho.»

65 Ac. do TR de Évora de 2/5/2013, Processo n. ${ }^{0}$ 590/08.0TTSTR.E1, Ac. do TR do Porto de 13/04/2015, Proc. ${ }^{\circ}$ 485/13.5TTPNF.P1 (não publicado, relatado por João Nunes) e Ac. do TR Lisboa, de 7/10/2015, Proc. ${ }^{\circ}$ 408/13.1TBV.L1-4. 
Em Espanha, a lei define o acidente de trabalho combinando a tese da ocasionalidade e a tese da causalidade de uma forma alternativa: o $\mathrm{n}^{\circ} 1$ do art. $^{\circ} 115^{\circ}$ da Ley General de la Seguridad Social ${ }^{66}$ refere que «Se entiende por accidente de trabajo toda lesión corporal que el trabajador sufra con ocasión o por consecuencia del trabajo que ejecute por cuenta ajena».

Contudo, na alínea b) do n. 5 do mesmo artigo, clarifica-se que «No impedirá la calificación de un accidente como de trabajo (...) la concurrencia de culpabilidad civil o criminal del empresario, de un compañero de trabajo del accidentado o de un tercero, salvo que no guarde relación alguna con el trabajo» (destaque nosso).

E a jurisprudência predominante nega a qualificação como acidente de trabalho se a motivação do crime foi exclusivamente pessoal e intrínseca à relação entre o agressor e a vítima e inexistir qualquer relação com a atividade laboral.

Veja-se o Acórdão de 20/02/2006 ${ }^{67}$ do Tribunal Supremo de Espanha, relativo ao caso do "asesino de la Baraja": o jovem trabalhador do aeroporto de Barajas que, tendo acabado o seu turno, esperava o autocarro para regressar a casa, quando levou um tiro na cabeça, desferido por um indivíduo que, deambulando pela rua, matava pessoas ao acaso. O mesmo Tribunal entendeu que «...la conclusión única que se obtiene es que cuando la agresión que sufre el trabajador por parte de un tercero - sea en el lugar de trabajo o in itinere - obedece a razones personales entre agresor y agredido, cobra fuerza la excepción legale el resultado lesivo de la agresión no puede calificarse como accidente de trabajo. Pero en el presente supuesto no ocurre así. Entre agresor y trabajador agredido no existía relación alguna previa al suceso que provocó la muerte del segundo».

O Tribunal fez referência a várias decisões suas, em torno da norma contida no n..$^{\circ} 5$ do art. ${ }^{\circ} 115^{\circ}$ da Ley de Seguridad Social, concretamente à sentença de 20/06/2002, segundo a qual «...no puede negarse que la actuación de un tercero, incluso con culpabilidad civil o criminal concurrente, no debe impedir, en algunos casos, la declaración de accidente de trabajo. Y así, cuando la actuación de ese tercero se revela que tiene su razón de ser en el trabajo realizado por la victima o con ocasión de este último, indudablemente, no se podrá negar el carácter de accidente laboral a la agresión sufrida en tales circunstancias. Sin embargo, cuando los hechos enjuiciados, aunque materialmente se produzcan en el trayecto que conduce al centro de trabajo y

66 Aprovada pelo Real Decreto Legislativo $n^{0}$ 1/94, de 20 de junho de 1994.

${ }_{67}$ Disponivel em http://www.belt.es/jurisprudencia/anterior/seg_ind_prl/prl/pdf/sentencia_at_initinere_ disparo.pdf 
precisamente cuando se inicia dicho trayecto, si responden a una motivación claramente ajena al trabajo, en sí mismo considerado, es evidente que a tenor del apartado b) del núm. 5 delart. 115 de la Ley de Seguridad Social de 1994, no puede calificárseles de propio accidente laboral. Se trataba en este último supuesto de trabajador muerto por un compañero a causa de problemas personales en torno a la esposa de uno de los afectados».

Já em França a opção é a oposta, pois o acidente de trabalho é independente da causa que o originar, bastando que ocorra por efeito ou por ocasião do trabalho; o art. ${ }^{\circ}$ L411-1 do Code de la Sécurité Sociale, dispõe que «Est considéré comme accident du travail, quelle qu'en soit la cause, l'accident survenu par le fait ou à l'occasion du travail à toute personne salariée ou travaillant, à quelque titre ou en quelque lieu que ce soit, pour un ou plusieurs employeurs ou chefs d'entreprise» (destaque nosso). Na verdade, a atuação de uma qualquer causa por ocasião do trabalho é suficientemente esclarecedora da mens legislatoris, na nossa perspetiva muito discutível, mas a que não será alheia, eventualmente, a circunstância de, mesmo tratando-se de situação que nada tenha que ver com a realidade laboral, o financiador ser o mesmo: a segurança social francesa.

No Brasil, o art. $^{\circ} 19^{\circ}$ da Lei 8.213, de 24/07/1991, apresenta a seguinte definição de acidente de trabalho: "Acidente do trabalho é o que ocorre pelo exercício do trabalho a serviço de empresa ou de empregador doméstico ou pelo exercício do trabalho dos segurados referidos no inciso VII do art. 11 desta Lei, provocando lesão corporal ou perturbação funcional que cause a morte ou a perda ou redução, permanente ou temporária, da capacidade para o trabalho».

E o art. $^{\circ} 21^{\circ}$ equipara a acidente do trabalho, entre outros:

- «o acidente ligado ao trabalho que, embora não tenha sido a causa única, haja contribuido diretamente para a morte do segurado, para redução ou perda da sua capacidade para o trabalho, ou produzido lesão que exija atenção médica para a sua recuperação» $\mathrm{e}$

"o acidente sofrido pelo segurado no local e no horário do trabalho, em consequência de ofensa física intencional, inclusive de terceiro, por motivo de disputa relacionada ao trabalho» (destaque nosso).

Portanto, as agressões de terceiros ou mesmo de colegas no local de trabalho ou no trajeto motivadas por questões estritamente pessoais não têm cabimento na tutela acidentária destes países, bem como na de muitos outros.

JÚLIO GOMES, refere que "No caso de a agressão proveniente de um colega ou, mesmo, de um terceiro, encontrar a sua razão de ser em motivos 
conexos com o trabalho tem-se verificado, ao nível do direito comparado, uma atitude mais recetiva à qualificação como acidente de trabalho. Existe, a invés, uma forte resistência, em alguns ordenamentos, em considerar como acidentes de trabalho as agressões de que o trabalhador seja vítima, mesmo no local e no tempo de trabalho, por razões inteiramente estranhas à relação laboral ou por razões que não foi possível apurar ${ }^{68} »$.

E dá o exemplo dos Estados Unidos, em que é acidente de trabalho a lesão que resulta de uma luta entre trabalhadores sempre que os motivos sejam conexos com o trabalho, mas se os motivos são puramente pessoais, mesmo que o conflito ocorra no local de trabalho, não há tanta recetividade em qualificar como acidente de trabalho. Por outro lado, no caso de conflitos pessoais, admite-se a qualificação se o trabalho facilitou a agressão (por exemplo, a vítima que, para fazer a medição de uns móveis, teve de se deslocar a casa de um cliente, que afinal era o ex-marido, o qual se serviu desse estratagema para a atacar).

Habitualmente, nos EUA, refere ainda o mesmo Autor, distinguem-se as situações em que o emprego ou o ambiente de trabalho facilitam a agressão por um terceiro e as situações em que tal não sucede e a agressão é estritamente motivada por razões pessoais, sendo que alguns estados excluem expressamente tais agressões.

O Autor dá ainda nota da doutrina italiana, segundo a qual a agressão de um trabalhador no local de trabalho ou no trajeto de e para o trabalho constitui acidente de trabalho, a menos que o agressor tenha agido por motivos estranhos ao trabalho e atinentes a relações interpessoais com a vítima ou os seus comportamentos, qualidades pessoais ou orientações políticas, religiosas, culturais e a conduta agressiva não foi possibilitada ou facilitada pela atividade laboral da vítima ou pelo trajeto que esta seguia.

\section{ii. Cotejo com as situações de exclusão da responsabilidade}

As situações de violação de condições de segurança, negligência grosseira, privação do uso da razão e caso de força maior devido a forças inevitáveis da natureza, são afastadas da reparação infortunística pois entende-se que é excessivo responsabilizar o empregador pelas mesmas. São situações em se verificam determinados fatores que se sobrepõem ao elo de ligação à relação laboral.

68 Ob. cit., p. 99 e 100. 
Mas, como veremos ao analisar cada uma, é forçoso concluir que existem motivos acrescidos para afastar as agressões determinadas por razões emergentes da vida privada do trabalhador.

Nos termos do n..$^{\circ} 1$ do art. $^{\circ} 9^{\circ}$ do Código Civil, a interpretação da lei «não deve cingir-se à respetiva letra, mas reconstituir a partir dos textos o pensamento legislativo, tendo sobretudo em conta a unidade do sistema jurídico, as circunstâncias em que a lei foi elaborada e as condições específicas do tempo em que é aplicada».

Ora, a unidade do sistema jurídico, no âmbito que ora nos ocupa, não pode senão apontar para o afastamento da tutela das contingências laborais de um crime doloso perpetrado sobre o trabalhador no local e tempo de trabalho, ou nas situações tipificadas como extensão do conceito de acidente de trabalho, por motivos alheios quer ao trabalho, quer à relação laboral, e exclusivamente atinentes à sua vida particular.

Por outro lado, da exegese das normas da LAT que definem o conceito de acidente de trabalho, tal como acima já se salientou, dificilmente resulta que o pensamento do legislador tenha pretendido abranger situações assaz desligadas da relação laboral.

Vejamos agora um pouco mais detidamente as quatro situações em que a lei afasta expressamente a reparação acidentária.

No que respeita à violação de condições de segurança por parte do trabalhador, a mesma pressupõe a verificação cumulativa dos seguintes requisitos ${ }^{69}$ :

- existência de condições de segurança estabelecidas pelo empregador ou previstas na lei

- ato ou omissão consciente ou voluntário, não relevando esquecimento, distração, inadvertência ou imperícia

- ausência de causa justificativa, consubstanciada em dificuldade no conhecimento ou entendimento das condições de segurança por motivo de deficiente grau de instrução ou falta de acesso à informação

- nexo de causalidade entre a violação de condições de segurança e o acidente

Assim, se um trabalhador violar conscientemente condições de trabalho e se daí resultar um acidente, o mesmo não é reparado. Parece justo e equilibrado, na economia da relação laboral; se o empregador estabeleceu uma regra de segurança e o trabalhador decidiu não a observar, acidentando-se, então não deve beneficiar da tutela infortunística, pois ao tomar aquela

${ }^{69}$ Cfr. ALEGRE, CARLOS,ob. cit. p. 61. 
decisão assumiu o risco por sua conta, deixando de estar sob a alçada da autoridade do empregador. Seria excessivamente injusto responsabilizá-lo pelo acidente que fez tudo para evitar, designadamente instituindo uma regra que, sendo observada, impediria a ocorrência do mesmo.

Estas asserções estão conformes ao espírito da LAT; contudo, parece-nos que é muito mais injusto considerar o empregador responsável pelas agressões que o trabalhador sofre por questões exclusivamente pessoais, atinentes à sua vida privada.

Se é negada a reparação em situações intimamente ligadas à prestação de trabalho, por virtude de ter ocorrido a interferência de um factor pessoal do trabalhador, no caso, a decisão de não respeitar uma regra de segurança, porquê aceitá-la quando tudo se confina a questões pessoais e a única "ligação" com o trabalho não passa de uma mera coincidência de tempo e de local?

Outro tanto se poderá dizer relativamente à negligência grosseira, definida na LAT como «o comportamento temerário em alto e relevante grau, que não se consubstancie em ato ou omissão resultante da habitualidade ao perigo do trabalho executado, da confiança na experiência profissional ou dos usos da profissão».

O comportamento despropositado, absurdo, inútil, gratuito do trabalhador também implica o afastamento da responsabilidade do empregador, o que faz todo o sentido. Vejamos um exemplo: o trabalhador que pratica motociclismo nos seus tempos livres, resolve fazer "cavalinho" a caminho do seu trabalho, de mota, e, por causa disso, sofre um acidente. Trata-se de uma questão eminentemente pessoal, totalmente desligada da relação laboral, pela qual o empregador não é, nem pode ser, responsável. Mas então porque deve sê-lo se, por exemplo, nesse trajeto, um outro motociclista com quem o trabalhador está desavindo, por causa de um incidente ocorrido entre ambos numa prova desportiva, resolve vingar-se, perseguindo-o e provocando-lhe um aparatoso acidente?

A privação permanente ou acidental do uso da razão também afasta a tutela legal. Pensemos num trabalhador que é toxicodependente e, de manhã, antes de ir para o trabalho, vai comprar uma dose de estupefaciente e toma-a. Já no trajeto para o trabalho, despista-se por virtude de ter desfalecido, em consequência do seu estado físico; o empregador não é responsável pelo acidente. Mas, se no trajeto for perseguido pelo traficante, por dívidas relativas à aquisição da substância, e tiver um acidente de viação provocado intencionalmente pelo mesmo traficante, o qual, lhe embate por 
trás e o faz despistar-se, ou então, o alveja com uma arma de fogo, porque tem o empregador de ser responsável por tais eventos ${ }^{70}$ ?

Tomemos, finalmente, o motivo de força maior. Entende-se que tratando-se de um evento gerado pela Natureza, a que o empregador é totalmente alheio, não deve o mesmo ser onerado com a reparação. Trata-se de situações que integram o conjunto de riscos a que a generalidade das pessoas está exposta, pelo simples facto de viver, pelo que é negada ao trabalhador a tutela infortunística, ainda que o mesmo seja igualmente alheio à origem do acidente. Portanto, se o trabalhador se dirige para o seu trabalho e é apanhado por uma torrente de água que transbordou de um rio, afogando-se, ou é atingido por um raio que o fulmina, os seus familiares ficam sem qualquer reparação.

Todavia, se o trabalhador se encontra num conflito de partilhas, num divórcio litigioso, numa disputa política, etc, e for atacado pelo seu inimigo naquele mesmo percurso, temos quem defenda que se trata de um acidente de trabalho indemnizável nos termos da LAT, pelo facto de o acidente ter ocorrido no trajeto garantido pela mesma.

Estamos perante factos totalmente alheios ao empregador e à própria relação laboral. Já outro tanto não se pode afirmar relativamente ao sinistrado, pois é da sua vida privada que se trata, na qual intervém decisivamente a sua maior ou menor conflituosidade, a sua capacidade de resolução pacífica dos problemas e de prevenção de querelas.

Trata-se de riscos que algumas pessoas correm, em diferentes graus, consoante vários fatores, desde logo a forma como conduzem a sua vida e os seus assuntos, mas também o simples acaso. Ora, sendo riscos relativos à sua vida privada, devem ficar contidos na sua esfera, correndo exclusivamente por sua conta e não onerando outrem.

Por outro lado, o empregador é tão alheio a esses eventos quanto o é relativamente às forças da Natureza, se não o for mais, pois que, conhecendo as previsões meteorológicas, pode tomar providências para evitar a deslocação do seu trabalhador ou providenciar-lhe um transporte mais seguro. Pode, inclusive, informar-se junto dos serviços de proteção civil sobre quais as medidas a tomar e/ou a recomendar ao trabalhador. Já quanto aos assuntos da vida privada deste, em regra, o empregador não os conhece, nem tem de conhecer e, ainda que conheça, pouco ou nada pode fazer. Porque deve então ser responsabilizado pelas agressões de que o sinistrado é vítima por

70 E não é o direito de regresso previsto no art. ${ }^{\circ} 17^{\circ}$ da LAT que repõe a justiça nestas situações, pois esse direito fica, na esmagadora maioria das vezes, sem concretização, por inviabilidade de cobrança do crédito. 
motivos atinentes à sua vida privada, quando não o é, e bem, relativamente a eventos causados pela Natureza?

Tal responsabilização parece-nos carecer de sentido, mesmo nas situações em que o agressor tenha decidido perpetrar o crime no percurso da vítima para o seu local de trabalho. Não cremos que isso, por si só, constitua razão suficiente para estabelecer a necessária conexão com a relação laboral.

$\mathrm{Na}$ verdade, as pessoas não saem de casa e não se deslocam apenas para ir trabalhar; fazem-no pelos mais diversos motivos, a horas mais ou menos certas e previsíveis, como comprar o pão ou o jornal pela manhã, levar os filhos à escola, ir ao café depois do almoço, passear o cão ao final da tarde, ir à missa, ao ginásio, ao estádio do seu clube, etc, etc, pelo que o facto de serem agredidas no percurso para o trabalho, não significa que haja uma relação causal entre a agressão e a relação laboral. As agressões podem ocorrer em múltiplos contextos.

Normalmente, não se pode afirmar que foi determinante para o cometimento do crime a vítima ter saído de casa para ir trabalhar, pois qualquer agressor pode perfeitamente perpetrar o crime noutra hora e noutro local. $\mathrm{E}$, especialmente no caso dos crimes passionais, o agressor conhece muito bem todas as rotinas da vítima. Aliás, alguns até vivem com elas e o facto de o crime ser perpetrado no trajeto para o trabalho ou no local de trabalho deve-se a fatores que nada têm que ver com essa circunstância específica. O local e o tempo de trabalho não determinam, obviamente, uma maior exposição da vítima ao perigo, como é bom de ver.

A conexão tem de ser consubstanciada em algo que vá para lá do circunstancial ou ocasional, sob pena de se cair no absurdo.

Para que um evento possa ser qualificado como acidente de trabalho tem sempre de lhe estar subjacente o risco criado pelo trabalho ou, em termos mais amplos, pela relação laboral do trabalhador. O empregador responde pelos riscos gerados pela sua atividade; ponto é que se saiba dilucidar até onde deve ir essa responsabilidade, a qual deve abranger apenas os riscos a que o trabalhador fica exposto por causa de trabalhar para a empresa.

O conteúdo da conexão entre o acidente e o trabalho ou a relação laboral tem de ser definido com racionalidade e objetividade. Não servirá tudo aquilo que aconteça e que, de alguma forma, por mais remota ou indireta que seja, esteja relacionado com o trabalho, ou, mais latamente, com o facto de o trabalhador estar ao serviço do empregador.

Existem, como já referido, alguns arestos que qualificam como acidente de trabalho lesões decorrentes de atos violentos de terceiros (colegas de 
trabalho ou terceiros alheios à relação laboral) ${ }^{71}$, aparentemente sem que tais atos tivessem motivações relacionadas com a atividade laboral. Contudo, todos os arestos que costumam ser citados pelos defensores da tese da ocasionalidade, versam sobre casos em que, independentemente das motivações do agressor, é patente uma conexão do evento com a relação laboral.

Por outro lado, não basta uma qualquer relação, uma conexão mínima, remota, quiçá hipotética, para se colocar estes eventos sob a tutela infortunística.

Vejamos ainda duas situações: a trabalhadora está na sua casa e é alvo de um assalto relacionado com um documento de trabalho importantíssimo que tem à sua guarda, ficando ferida. Ou é atacada porque vai ser testemunha em tribunal de factos sensíveis, de que tomou conhecimento no exercício das suas funções. Parece justo considerar que foi vítima de um acidente de trabalho, pois a conexão é óbvia.

Essa mesma trabalhadora está em casa e o marido ataca-a porque tomou conhecimento, através do telemóvel que a empresa forneceu à vítima, de que ela tem um relacionamento extraconjugal com um colega de trabalho. Para quem entenda que basta uma ligação mínima com o trabalho para fundamentar a qualificação como acidente de trabalho, estamos em crer que não hesitará em considerar que neste caso essa "ligação" existiu.

De resto, e ainda a propósito do aresto relativo ao caso da pastilha elástica, diremos que, concordando-se integralmente e sem reservas com a decisão nele tomada, se mostra ser menos injusto considerar como acidente de trabalho a morte no local de trabalho, por asfixia causada por uma pastilha elástica, do que o homicídio no trajeto para o trabalho, perpetrado, por exemplo, pelo namorado da vítima, por motivos passionais.

71 Ac. do STJ de 8/02/1995, Proc. $^{\circ}$ 004142, relativo à morte decorrente de dois disparos efetuados na sequência de um assalto que ocorreu quando o trabalhador saía do restaurante que geria, para lhe tirar as chaves do cofre do restaurante; Ac. TR Porto de 8/7/2004,Proc. ${ }^{\circ}, 0411916$, relativo às lesões provocadas a um trabalhador por causa de uma brincadeira de mau gosto por parte de um colega de trabalho, utilizando a bomba de ar comprimido com que desempenhava o seu trabalho; Ac. TR Lisboa de 22/6/2005, Proc. ${ }^{\circ}$ 107555/2004-4, no âmbito de uma agressão de um terceiro ao trabalhador que ia iniciar o seu trabalho às 2 h30 da madrugada; Ac. do STJ de 28/3/2007, Proc. ${ }^{\circ}$ 06S3957, concernente ao assalto por "esticão" que provocou a morte da trabalhadora, no percurso laboral, de noite, em lugar deserto; Ac. TR Évora, Proc. ${ }^{\circ}$ 96/08.7TTPTM.E1, que considera acidente de trabalho o pontapé/encontrão dado, por mera brincadeira, por um colega de trabalho, quando desempenhavam as suas funções e o Ac. do STJ de 30/5/2012, Proc. ${ }^{\circ}$ 159/05.0TTPRT.P1S1, relativo a um episódio de violência por parte de um passageiro embriagado durante um voo comercial, que causou na assistente de bordo uma perturbação, determinante de incapacidade permanente para o trabalho. 
Afigura-se inaceitável conferir maior proteção aos eventos que ocorrem no trajeto laboral do que aos eventos que ocorrem no próprio local e tempo de trabalho, por natureza muito mais conexos com a prestação o trabalho.

Considerar que tudo quanto aconteça no trajeto laboral é acidente de trabalho é permitir que esta extensão do conceito de acidente de trabalho assuma uma preponderância desajustada sobre as situações verificadas no tempo e no local de trabalho.

Destarte, cremos que os defensores da tese da tutela generalizada do trajeto laboral, considerariam ter-se tratado de um acidente de trabalho se a sinistrada do caso acima mencionado tivesse morrido asfixiada por causa da pastilha elástica já a caminho de casa.

\section{Conclusão}

O conceito de acidente de trabalho pressupõe a verificação cumulativa dos seguintes elementos:

- acidente: facto ou evento naturalístico cuja verificação é

- ocasional, imprevista

- súbita, repentina, de duração curta e limitada no tempo

- de origem externa à constituição da vítima

- lesiva ou danosa para a constituição da vítima

- de trabalho: ocorrido

- no local de trabalho

- no tempo de trabalho e

- verificando-se:

- um nexo de causalidade entre:

- o trabalho ou a relação laboral e o evento

- o evento e a lesão

- a lesão e a incapacidade ou a morte

O acidente de trabalho não tem de resultar diretamente da execução do trabalho, mas deve ter sempre a sua origem num risco de natureza laboral.

A qualificação de um evento como acidente de trabalho pressupõe, pois, uma conexão ou causalidade com a prestação laboral ou, pelo menos, com a relação laboral.

Essa conexão deve configurar-se como eficiente, sem a qual o acidente não ocorreria, ou previsivelmente não ocorreria, e não meramente circunstancial ou ocasional. 
O acidente in itinere pressupõe igualmente a verificação dessa conexão, à semelhança do acidente ocorrido no local e no tempo de trabalho ou nas demais circunstâncias previstas como extensão do conceito de acidente de trabalho.

\section{Referências bibliográficas}

ALEGRE C. Acidentes de Trabalho e Doenças Profissionais, 2a edição, 2000

CARVALHO JAC. Acidentes de Trabalho e Doenças Profissionais, Legislação Anotada, Petrony, 2. ${ }^{\text {a }}$ edição, 1983

DOMINGOS MA. Algumas Questões Relacionadas com o Conceito de Acidente de Trabalho, Prontuário de Direito do Trabalho, n. ${ }^{\text {os }} 76,77$ e 78, 2007

DOMINGOS MA, REIS V, RAVARA D. Caderno de Acidentes de Trabalho e Doenças Profissionais, Coleção Formação Inicial, Centro de Estudos Judiciários, 2013

FERNANDES M. Noções Fundamentais de Direito do Trabalho, 5. a edição, 1986

GOMES JMV. O Acidente de Trabalho - $O$ acidente in itinere e a sua descaraterização, 2013

LEITÃO LM. Acidentes de Trabalho e Responsabilidade Civil (A Natureza Jurídica da Reparação de Danos Emergentes de Acidentes de Trabalho e a Distinção entre as Responsabilidades Obrigacional e Delitual), ROA, 1993

LEITÃO LM. A reparação de danos emergentes de acidentes de trabalho, Estudos do Instituto de Direito do Trabalho, Vol. I, 2001

LEITÃo LM. Direito do Trabalho, Almedina, 2. ${ }^{a}$ edição, 2010

MARTINEZ PR. Direito do Trabalho, Almedina, 6. ${ }^{\text {a }}$ edição, 2013

MONTEIRO J. Fase Conciliatória do Processo Para A Efetivação De Direitos Resultantes de Acidente de Trabalho - Enquadramento e Tramitação, Prontuário de Direito do Trabalho $n^{\circ} 87$

PIRES FA. Seguro de Acidentes de Trabalho, Lex, 1999

RAMALHO MRP. Direito do Trabalho, Parte II - Situações Laborais Individuais, Almedina, 3. ${ }^{\text {a }}$ edição, 2010

RIBEIRO V. Acidentes de Trabalho, Reflexões e Notas Práticas, Rei dos Livros, 1984

VARELA A. Das Obrigações em geral, Almedina, 4. a edição, 1982

XAVIER BL. Manual de Direito do Trabalho, 2011 